\title{
PROGRAM BOOK
}

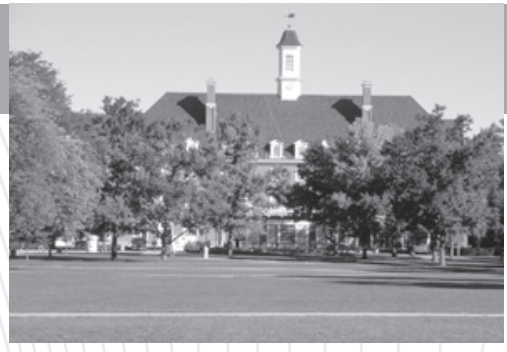

8th International Congress on

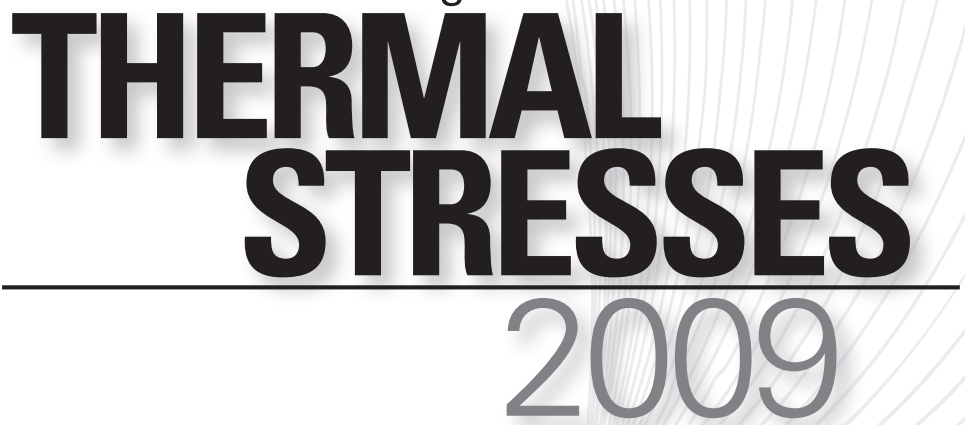

JUNE 1-4, 2009

University of Illinois at Urbana-Champaign, Illinois, USA 


\section{Preface}

The 8th International Congress on Thermal Stresses, TS 2009, was held from May 31 to June 4, 2009, at the University of Illinois at Urbana-Champaign. The Organizing Committee received nearly 150 contributions from a number of countries. Following a review process, 146 papers were accepted for final presentation at the congress and publication in these proceedings. Nearly half of all the papers were submitted directly to special symposia, and these, with their respective organizers, are:

- Professor Liviu Librescu Memorial Symposium organized by Pier Marzocca and Marek-Jerzy Pindera

- Fracture and Deformations in Functional Materials and Structures organized by Sei Ueda, Nao-Aki Noda, Cun-Fa Gao, and Zheng Zhong

- Second Sound and Thermal Shock Phenomena organized by Pedro Jordan

At the congress we were also privileged to have outstanding keynote lectures by

- Louis M. Brock, University of Kentucky, USA

- David G. Cahill, University of Illinois at Urbana-Champaign, USA

- Ching-Kong Chao, National Taiwan University of Science and Technology, Taiwan

- Artur Ganczarski and Jacek Skrzypek, Cracow University of Technology, Poland

- Paul M. Goldbart, University of Illinois at Urbana-Champaign, USA

- Gerard A. Maugin, Université Pierre et Marie Curie, France

- Walter Noll, Carnegie Mellon University, USA

- Yoshihiro Ootao, Osaka Prefecture University, Japan

The Congress gratefully acknowledges the valuable efforts of the special symposia organizers and all the reviewers. As Congress Chair, I am greatly indebted to the Congress Co-Chairs, Professors Richard B.

Hetnarski and Pier Marzocca, for their guidance in planning the Congress. Special thanks go to Ms. Michelle Chappell with the Conferences \& Institutes division of the Office of Continuing Education at the University of Illinois for continuing assistance, efficient planning, and patient management of a multitude of tasks associated with the organization of the congress. Last, but not least, the congress gratefully acknowledges the support by the University of Illinois (and especially the Department of Mechanical Science \& Engineering), Clarkson University, The Air Force Office of Scientific Research, and the National Science Foundation.

Martin Ostoja-Starzewski Congress Chair 


\section{Congress Schedule}

Sunday, May 31, 2009

$\begin{array}{lll}\text { 16:00-20:00 } & \text { Registration } & \text { Colonial Room } \\ \text { 18:00-20:00 } & \text { Welcome Reception } & \text { Colonial Room }\end{array}$

Monday, June 1, 2009

8:00

Registration

3rd Floor

9:00-9:30 Congress Opening Ceremony

9:30-10:30 Keynote Lecture:

314

"On the propagation of singular surfaces in thermoelasticity"

G.A. Maugin

$10: 30-11: 30$

Keynote Lecture:

"Basic problems of coupled thermoelasticity with thermal relaxation and pre-stress: Aspects observed in exact and asymptotic solutions"

L.M. Brock

11:30 Group Photo

314

12:00-13:20 Lunch

2nd Floor Ballroom

13:20-14:20 Keynote Lecture:

"Thoughts on thermomechanics"

314

W. Noll

14:30-18:00 Technical Sessions

4th Floor

Tuesday June 2, 2009

\begin{tabular}{|c|c|}
\hline $8: 30-9: 30$ & $\begin{array}{l}\text { Keynote Lecture: } \\
\text { "Heterogeneous problems in plane thermoelasticity" } \\
\text { C.K. Chao }\end{array}$ \\
\hline 10:00-12:00 & Technical Sessions \\
\hline 12:00-13:20 & Lunch \\
\hline $13: 20-14: 20$ & $\begin{array}{l}\text { Keynote Lecture: } \\
\text { "Coupled thermo-elasto-plastic damage models and } \\
\text { application to some innovative materials" } \\
\text { A. Ganczarski and J. Skrzypek }\end{array}$ \\
\hline $14: 30-17: 00$ & Technical Sessions \\
\hline 19:00-21:00 & $\begin{array}{l}\text { Congress Banquet } \\
\text { "Walk-Around Magic" with Ben Rahimi }\end{array}$ \\
\hline
\end{tabular}

314

4th Floor

2nd Floor Ballroom

314

4th Floor

2nd Floor Ballroom 


\section{Wednesday, June 3, 2009}

8:30-9:30 Keynote Lecture:

"Transient thermoelastic and piezothermoelastic problems of functionally graded materials"

Y. Ootao

\begin{tabular}{|c|c|}
\hline $10: 00-12: 00$ & Technical Sessions \\
\hline $12: 00-13: 20$ & Lunch \\
\hline $13: 20-14: 20$ & $\begin{array}{l}\text { Keynote Lecture: } \\
\text { "Heterogeneous solids and the micro/macro connection: } \\
\text { Structure and elasticity in architecturally complex media as } \\
\text { emergent collective phenomena" } \\
\text { P.M. Goldbart }\end{array}$ \\
\hline
\end{tabular}

14:30-17:00 Technical Sessions

\section{Thursday, June 4, 2009}

$8: 30-9: 30$

Keynote Lecture:

"Spatially resolved measurements of thermal stresses by picosecond time-domain probe beam deflection" D.G. Cahill

$10: 00-12: 00$

12:00-13:20

12:00-18:00

\section{Technical Sessions}

Lunch

Excursion to Abraham Lincoln Presidential Library and Museum in Springfield, IL (box lunch on bus)
314

4th Floor

2nd Floor Ballroom

314

4th Floor

314

4th Floor

2nd Floor Ballroom

Meet in 1st Floor Lobby

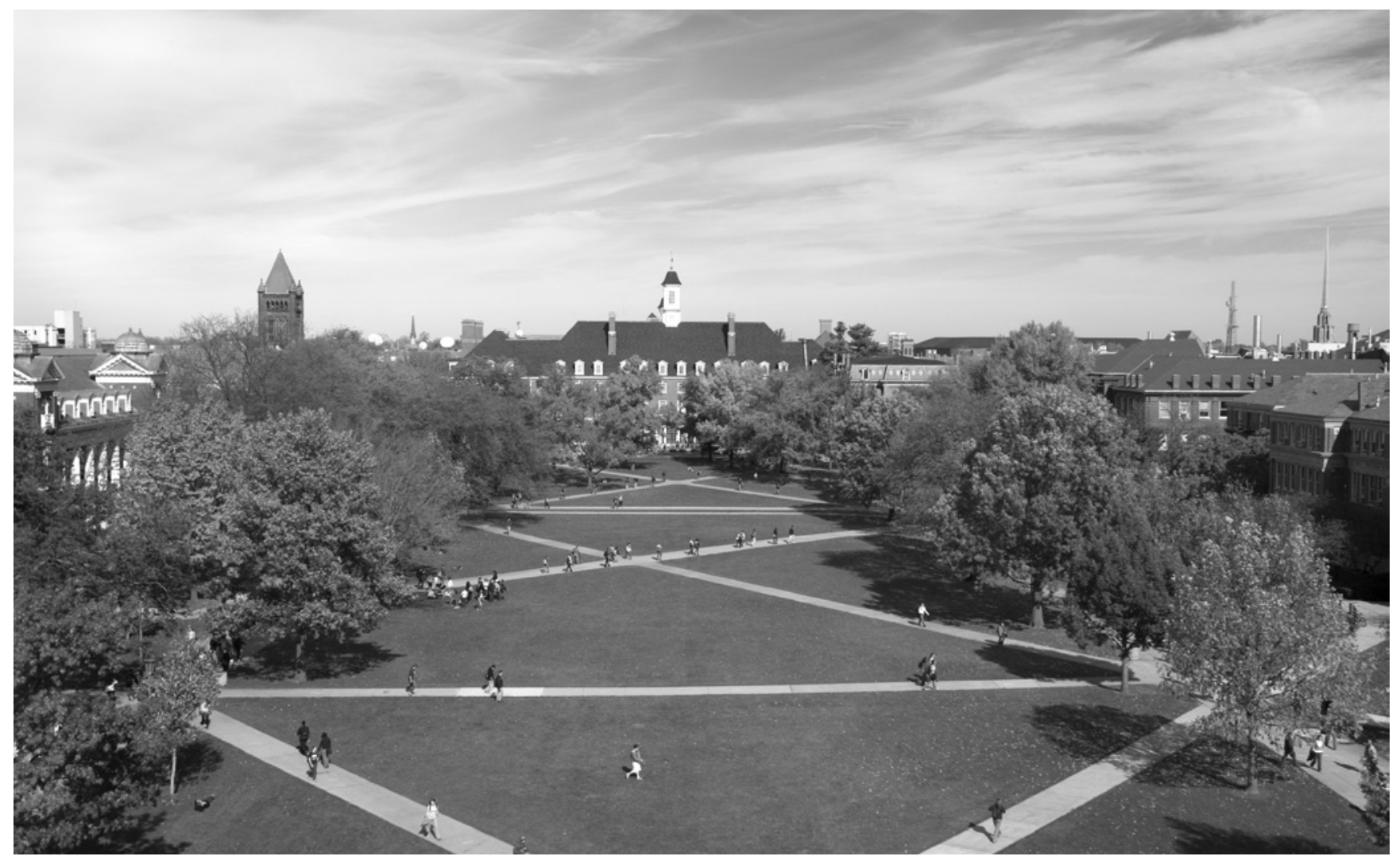




\section{Committees}

\section{General Chair}

Professor Martin Ostoja-Starzewski

Department of Mechanical Science and Engineering

University of Illinois at Urbana-Champaign

1206 Green West Street, Urbana, IL 61801, USA

Phone: 217-265-0900; Fax: 217-244-9980

E-mail: martinos@illinois.edu

\section{Co-Chairs}

\section{Professor Richard B. Hetnarski}

Professor Emeritus

Rochester Institute of Technology

St. Raphael, Apt. 1209, 7117 Pelican Bay Blvd.

Naples, FL 34108, USA

E-mail: 632hetna@rit.edu

\section{Professor Pier Marzocca}

Department of Mechanical and Aeronautical Engineering

The Wallace H. Coulter School of Engineering

Clarkson University

Potsdam, New York 13699-5725, USA

Phone: 315-268-3875; Fax: 315-268-6695

E-mail: pmarzocc@clarkson.edu

\section{Professor Naotake Noda}

Department of Mechanical Engineering

Shizuoka University

Johoku 3-5-1, Hamamtsu 432-8561, Japan

Fax: +81534781030

E-mail: tmnnoda@ipc.shizuoka.ac.jp

\section{International Congresses on Thermal Stresses (ICTS)}

The 8th International Congress on Thermal Stresses has been arranged by the International Congresses on Thermal Stresses (ICTS). The ICTS organization is affiliated with the International Union of Theoretical and Applied Mechanics (IUTAM).

The ICTS governs through the following two committees:

\section{The International Committee of ICTS}

James R. Barber

University of Michigan, Ann Arbor, MI, USA

Bruno A. Boley

Columbia University, New York, NY, USA
Klaus Herrmann

University of Paderborn, Paderborn, Germany

Richard B. Hetnarski

Rochester Institute of Technology, Rochester, NY, USA

Jozef Ignaczak

Polish Academy of Sciences, Warsaw, Poland

Gérard A. Maugin

Université Pierre et Marie Curie, Paris, France

Lodovico Nappa

Universitá degli Studi di Napoli Federico II, Napoli, Italy

Naotake Noda

Shizuoka University, Hamamatsu, Shizuoka, Japan

Naobumi Sumi

Shizuoka University, Shizuoka City, Shizuoka, Japan

Kumar Tamma

University of Minnesota, Minneapolis, USA

Yoshinobu Tanigawa

Osaka Prefecture University, Sakai, Osaka, Japan

Andrzej Tylikowski

Warsaw University of Technology, Warsaw, Poland

Kazumi Watanabe

Yamagata University, Yonezawa, Yamagata, Japan

\section{The Executive Committee of ICTS}

Ching-Kong Chao

National Taiwan University of Science and Technology

(NTUST), Taipei, Taiwan

Richard B. Hetnarski

President of ICTS

Rochester Institute of Technology, Rochester, NY, USA

Rudolf Heuer

Vienna University of Technology, Vienna, Austria

Naotake Noda

Shizuoka University, Hamamatsu, Japan

Jacek Skrzypek

Cracow University of Technology, Cracow, Poland

Kumar Tamma

University of Minnesota, Minneapolis, MN, USA

Yoshinobu Tanigawa

Osaka Prefecture University, Sakai, Osaka, Japan

Theodore R. Tauchert

Secretary-General of ICTS

University of Kentucky, Lexington, KY, USA

Franz Ziegler

Vienna University of Technology, Vienna, Austria 
International Scientific Committee

of the 8th International Congress on

Thermal Stresses

F. Ashida (Shimane University, Japan)

J.R. Barber (University of Michigan, USA)

B.A. Boley (Columbia University, USA)

C.-K. Chao (NTUST, Taiwan)

M. Reza Eslami (Amirkabir University of Technology, Iran)

D. Hasanyan (Analytical Services \& Materials, Inc., USA)

K.P. Herrmann (Universitat Paderborn, Germany)

R. Heuer (Vienna University of Technology, Austria)

H.H. Hilton (University of Illinois, USA)
J. Ignaczak (Polish Academy of Sciences, Poland)

H. Irschik (University of Linz, Austria)

I. Jasiuk (University of Illinois, USA)

P. Jordan (Naval Research Laboratory, USA)

Yu.A. Rossikhin (Voronezh State University, Russia)

J.J. Skrzypek (Cracow University of Technology, Poland)

M.V. Shitikova (Voronezh State University, Russia)

K.K. Tamma (University of Minnesota, USA)

Y. Tanigawa (University of Osaka Prefecture, Japan)

T.R. Tauchert (University of Kentucky, USA)

A. Tylikowski (Warsaw University of Technology, Poland)

F. Ziegler (Vienna University of Technology, Austria)

\section{Other ICTS Congresses (the first two were called Symposia)}

First International Symposium on Thermal Stresses and Related Topics

Thermal Stresses '95

Shizuoka University, Hamamatsu, Japan

Principal local organizer: Naotake Noda

June 5-7, 1995

Second International Symposium on Thermal Stresses and Related Topics

Thermal Stresses '97

Rochester Institute of Technology, Rochester, New York, USA

Principal local organizer: Richard B. Hetnarski

June 8-11, 1997

\section{Third International Congress on Thermal Stresses}

Thermal Stresses '99

Krakow University of Technology, Krakow, Poland

Principal local organizer: Jacek Skrzypek

June 13-17, 1999

\section{Fourth International Congress on Thermal Stresses}

Thermal Stresses '01

Osaka Prefecture University in cooperation with

Osaka Institute of Technology, Osaka, Japan

Principal local organizer: Yoshinobu Tanigawa

June 8-11, 2001
Fifth International Congress on Thermal Stresses

Thermal Stresses '03

Virginia Polytechnic Institute and State University

Blacksburg, Virginia, USA

Principal local organizer: Liviu Librescu

June 8-11, 2003

\section{Sixth International Congress on Thermal Stresses}

Thermal Stresses '05

Technische Universitat, Vienna, Austria

Principal local organizers: Rudolf Heuer and

Franz Ziegler

May 26-29, 2005

Seventh International Congress on Thermal Stresses

Thermal Stresses '07

National Taiwan University of Science and Technology

(NTUST), Taipei, Taiwan

Principal local organizer: Ching-Kong Chao

June 4-7, 2007

\section{Eighth International Congress on Thermal Stresses}

Thermal Stresses '09

University of Illinois at Urbana-Champaign, Illinois, USA

Principal local organizer: Martin Ostoja-Starzewski

June 1-4, 2009 


\section{Overview}

The objective of the international Congress is to provide an open forum for scientists and engineers to exchange ideas, interact cooperatively, and to foster the development and dissemination of basic and applied research on the topics related to the Congress. The Congress attracts participants from academia, research labs, and industry, who are involved in problems where temperature has an impact on the properties and behavior of materials and structures, on aerodynamics and or hydrodynamics, or other field interactions. The Congress seeks to forge cooperative links between researchers and engineers by bringing them together to present and listen to current research in these areas. Participants from all over the world are welcome to attend the Congress.

\section{Sponsors}

The Organizing Committee of TS 2009 expresses the gratitude for the generous support provided by:

University of Illinois, AFOSR, NSF, Clarkson University, ICTS, IUTAM
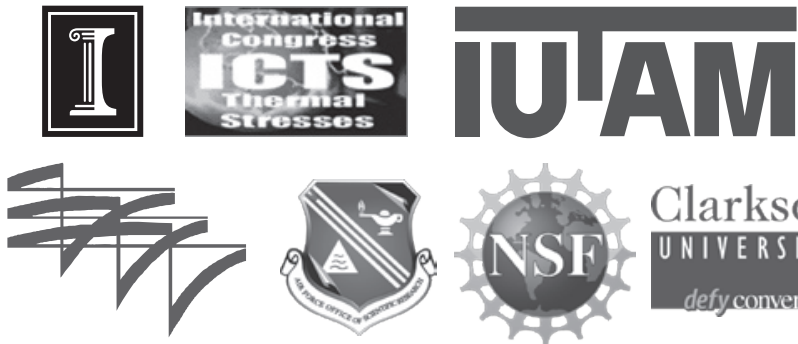

Clarkson UNIVERSITY

\section{General Information}

\section{Conference Proceedings}

The conference proceedings will be included on a USB flash drive.

\section{Timing of Presentations}

Each paper will be allotted 20 minutes (including introduction and question-and-answer period) except where noted.

\section{Restrictions}

Videotaping or audio recording of sessions or technical exhibits as well as the unauthorized sale of copyrighted material is prohibited.

\section{Audiovisual Equipment}

Each of the session rooms will have the following equipment: one LCD computer projector, one screen, one overhead projector and one pointer, microphones as appropriate. Any additional equipment will be at the cost of the user. Please note that computers will not be provided and it is the responsibility of each presenter to bring or arrange for a computer. Mac users should provide VGA cable connector. All application software installed should have the capability of outputting VGA signal within the screen resolutions of $1024 \times 768$ horizontal with a vertical refresh rate of $75 \mathrm{hz}$. As a backup, presenters should also come prepared to give their presentation by overhead projector if necessary. The standard electrical current is $120 \mathrm{v}$ at $60 \mathrm{~Hz}$. Power converters will not be provided.

\section{Journal Publication}

Authors of appropriate papers are encouraged to submit them for possible publication in the Journal of Thermal Stresses. For information, please visit http://www.tandf. co.uk/journals/tf/01495739.html

Editor-in-chief: Richard B. Hetnarski, St. Raphael, Unit 1209, 7117 Pelican Bay Blvd., Naples, FL 34108, USA (632hetna@rit.edu)

\section{Special Events}

Excursion to the Abraham Lincoln Presidential Library and Museum in Springfield, IL, on June 4, 12:00-18:00.

\section{Messages and Information}

Messages will be recorded on a bulletin board in the registration area. It is not possible to page attendees.

\section{Committee Meeting}

Meeting room locations will be posted on the message board and will be available in the registration area. Committees of International Congress of Thermal Stresses (ICTS) will meet at the Illini Union, room 404, Tuesday, June 2, 17:00-18:00. This meeting is for members only.

\section{Smoking Policy}

The University of Illinois is a smoke-free environment. Smoking is allowed outside in designated areas. 


\section{Program at a Glance}

\begin{tabular}{|c|c|c|c|}
\hline Day \& Time & $\begin{array}{l}\text { Librescu Memorial } \\
\text { Symposium Room } 407\end{array}$ & Room 406 & Room 405 \\
\hline $\begin{array}{l}\text { Monday } \\
14: 30-16: 10\end{array}$ & Piezo-Effect & $\begin{array}{l}\text { Inhomogeneity, Nonlinearity, } \\
\text { \& Voids }\end{array}$ & Thermoelasticity \\
\hline $\begin{array}{l}\text { Monday } \\
16: 20-18: 00\end{array}$ & Thermal Stresses I & $\begin{array}{l}\text { Thermomechanics, } \\
\text { Nanoeffects }\end{array}$ & Piezo-Thermoelasticity \\
\hline $\begin{array}{l}\text { Tuesday } \\
\text { 10:00-12:00 }\end{array}$ & Buckling \& Stability & Contact \& Instability & $\begin{array}{l}\text { Fracture and Deformations } \\
\text { in Functional Materials and } \\
\text { Structures }\end{array}$ \\
\hline $\begin{array}{l}\text { Tuesday } \\
14: 30-15: 50\end{array}$ & Thermal Stresses II & Wave Propagation & $\begin{array}{l}\text { Magneto- and Micropolar- } \\
\text { Thermoelasticity }\end{array}$ \\
\hline $\begin{array}{l}\text { Tuesday } \\
16: 00-17: 00\end{array}$ & $\begin{array}{l}\text { Delamination \& Fiber } \\
\text { Reinforced Materials }\end{array}$ & Films, Coatings, Layers & Casting \& Solidification \\
\hline $\begin{array}{l}\text { Wednesday } \\
\text { 10:00-12:00 }\end{array}$ & $\begin{array}{l}\text { Fracture, Elastoviscoplasticity, } \\
\text { \& Collisions }\end{array}$ & $\begin{array}{l}\text { Heat Transfer, Conduction, \& } \\
\text { Diffusion }\end{array}$ & Fracture \& Damage \\
\hline $\begin{array}{l}\text { Wednesday } \\
14: 30-15: 50\end{array}$ & $\begin{array}{l}\text { Functionally Graded } \\
\text { Structures }\end{array}$ & Second Sound I & Industry Problems \\
\hline $\begin{array}{l}\text { Wednesday } \\
16: 00-17: 40\end{array}$ & Friction \& Inclusions & Second Sound II & Composites \\
\hline $\begin{array}{l}\text { Thursday } \\
\text { 10:00-12:00 }\end{array}$ & Magnetic Effects \& Welding & Mixtures, Dissimilar Materials & $\begin{array}{l}\text { Beams, Plates, Bars, Disks, \& } \\
\text { Cylinders }\end{array}$ \\
\hline
\end{tabular}

\section{Professor Liviu Librescu Memorial Symposium}

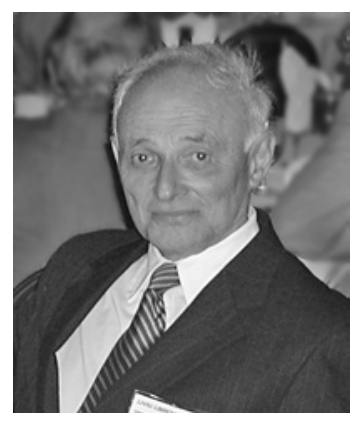

Professor Liviu Librescu

(August 18, 1930-April 16, 2007)

\section{Co-Organizers:}

Pier Marzocca, Clarkson University

Marek-Jerzy Pindera, University of Virginia 

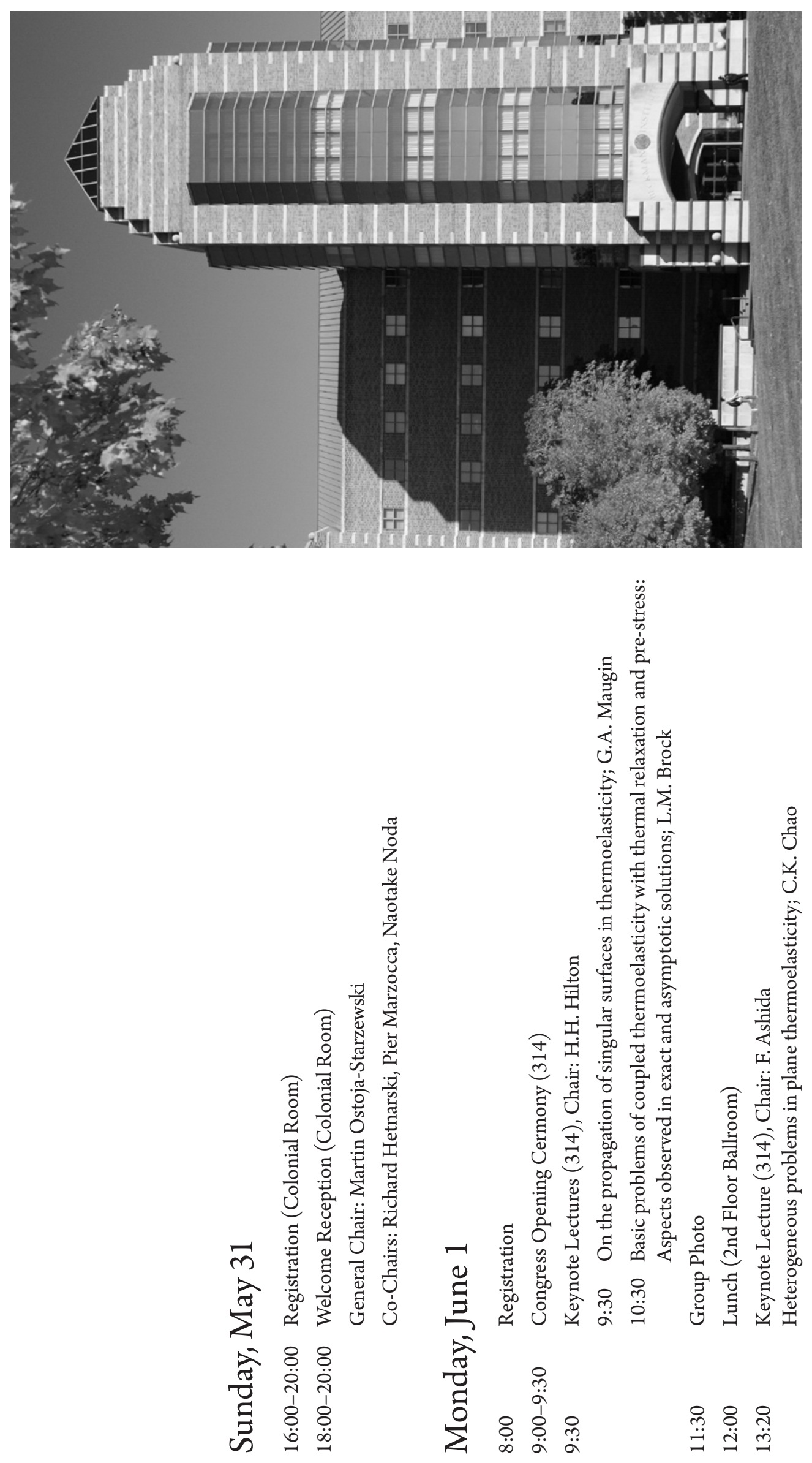


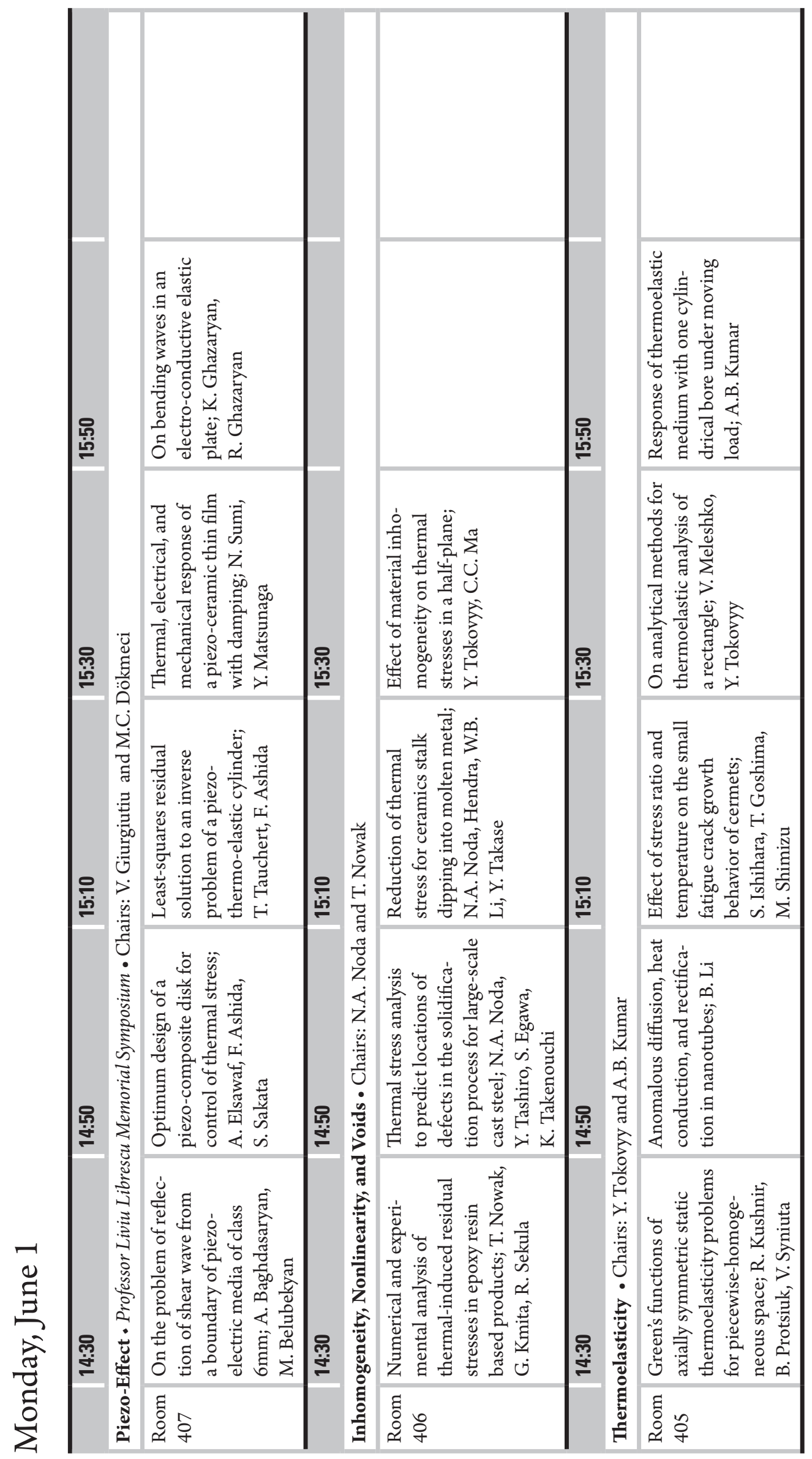




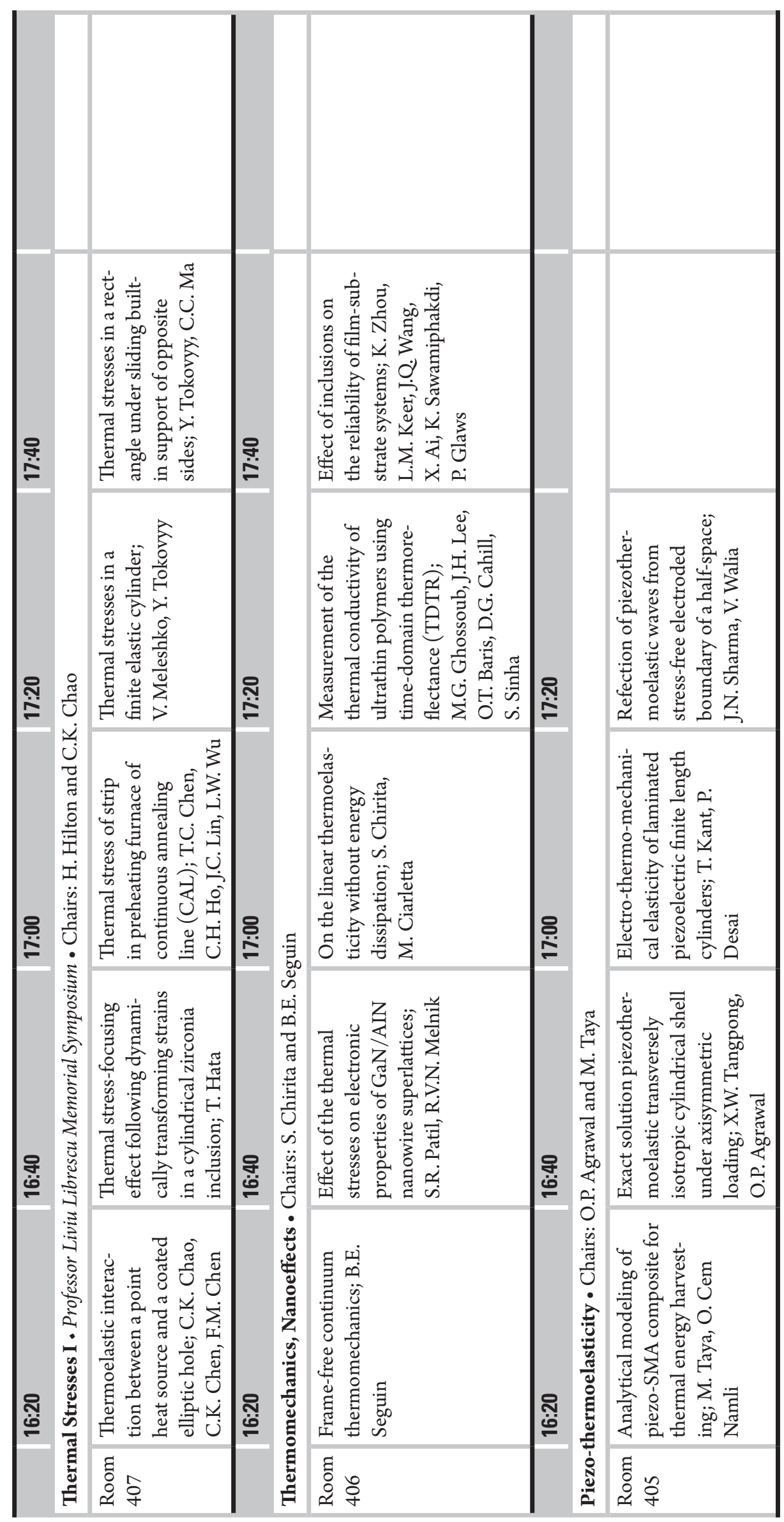




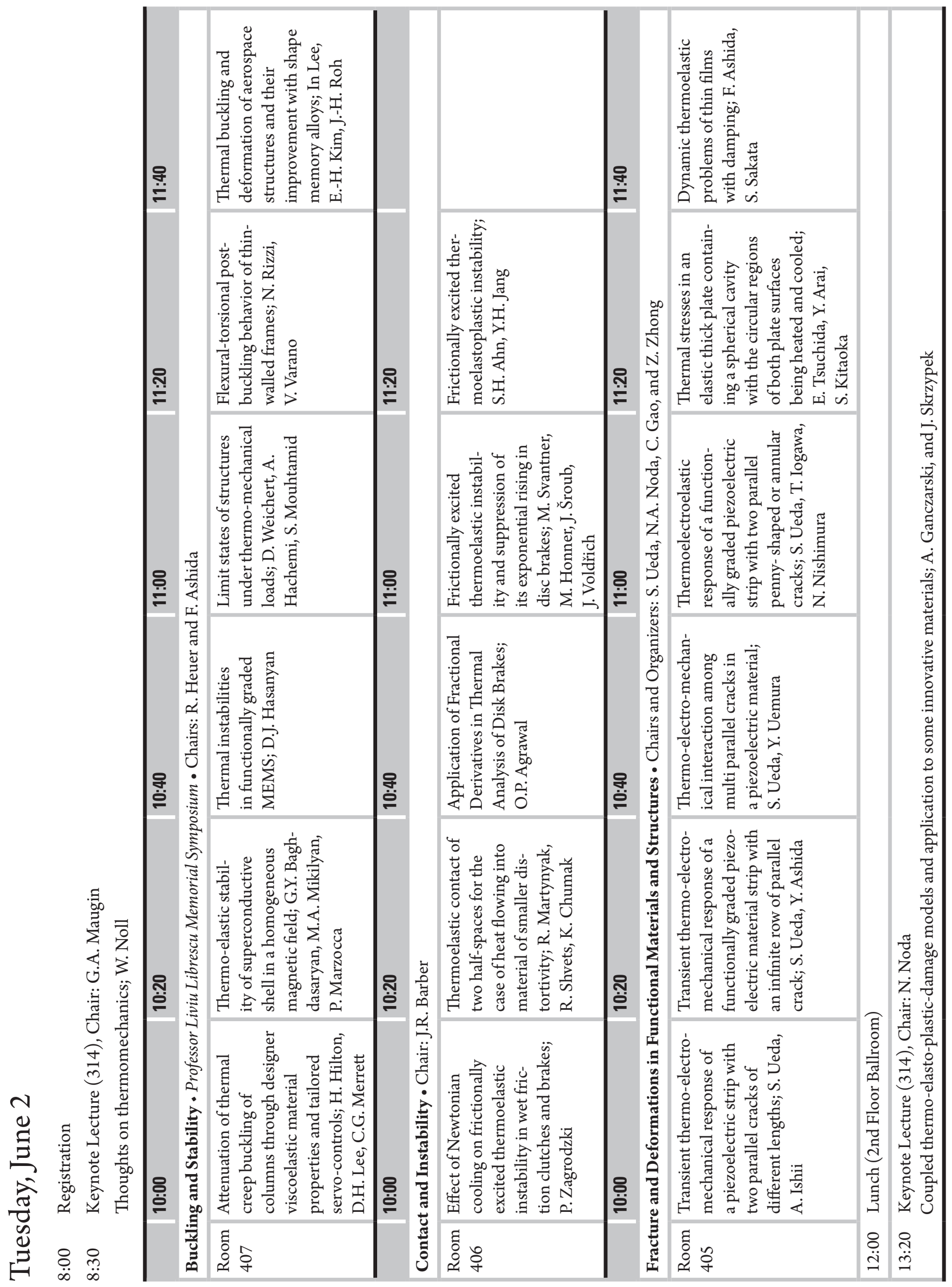




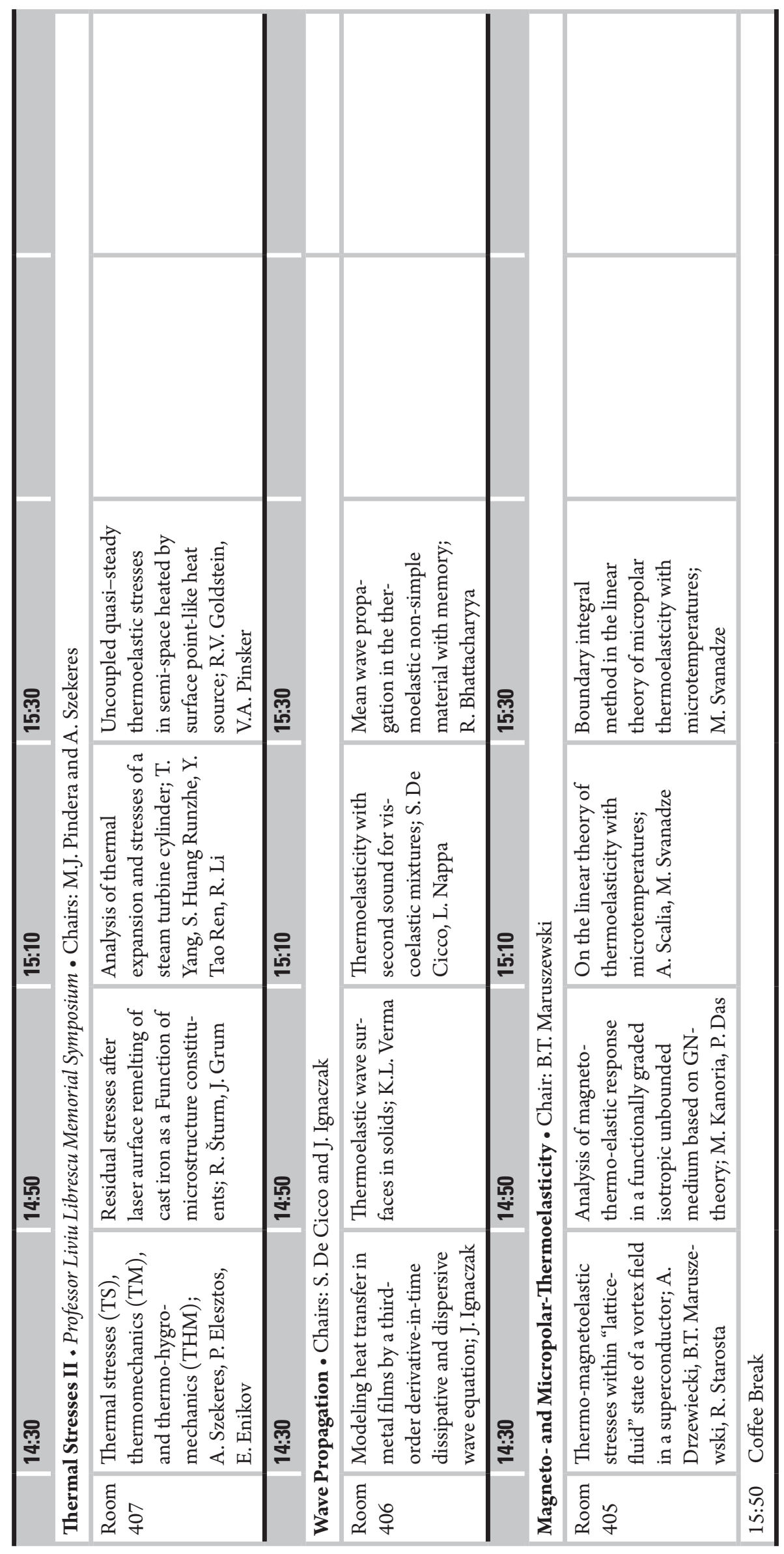




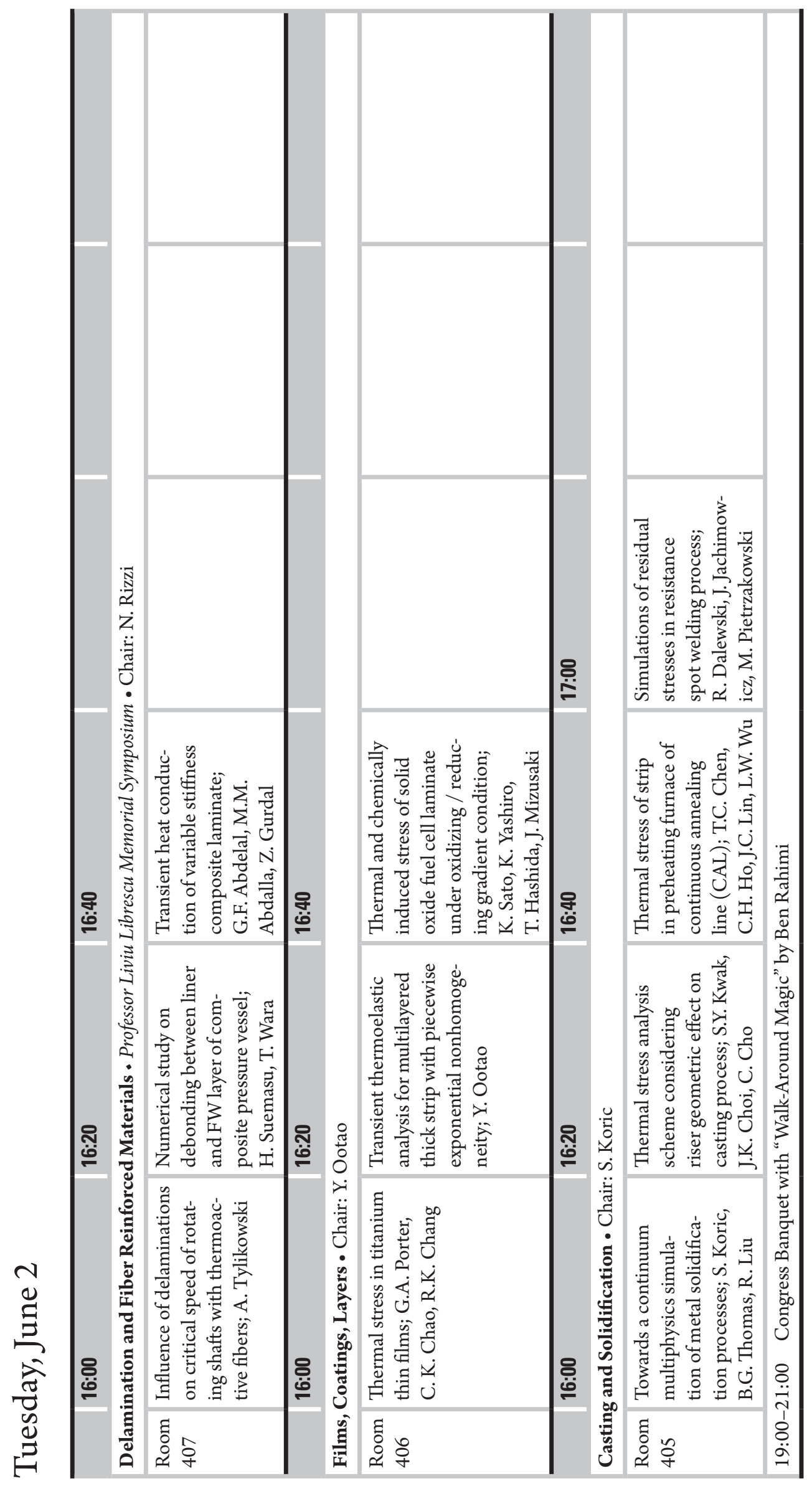




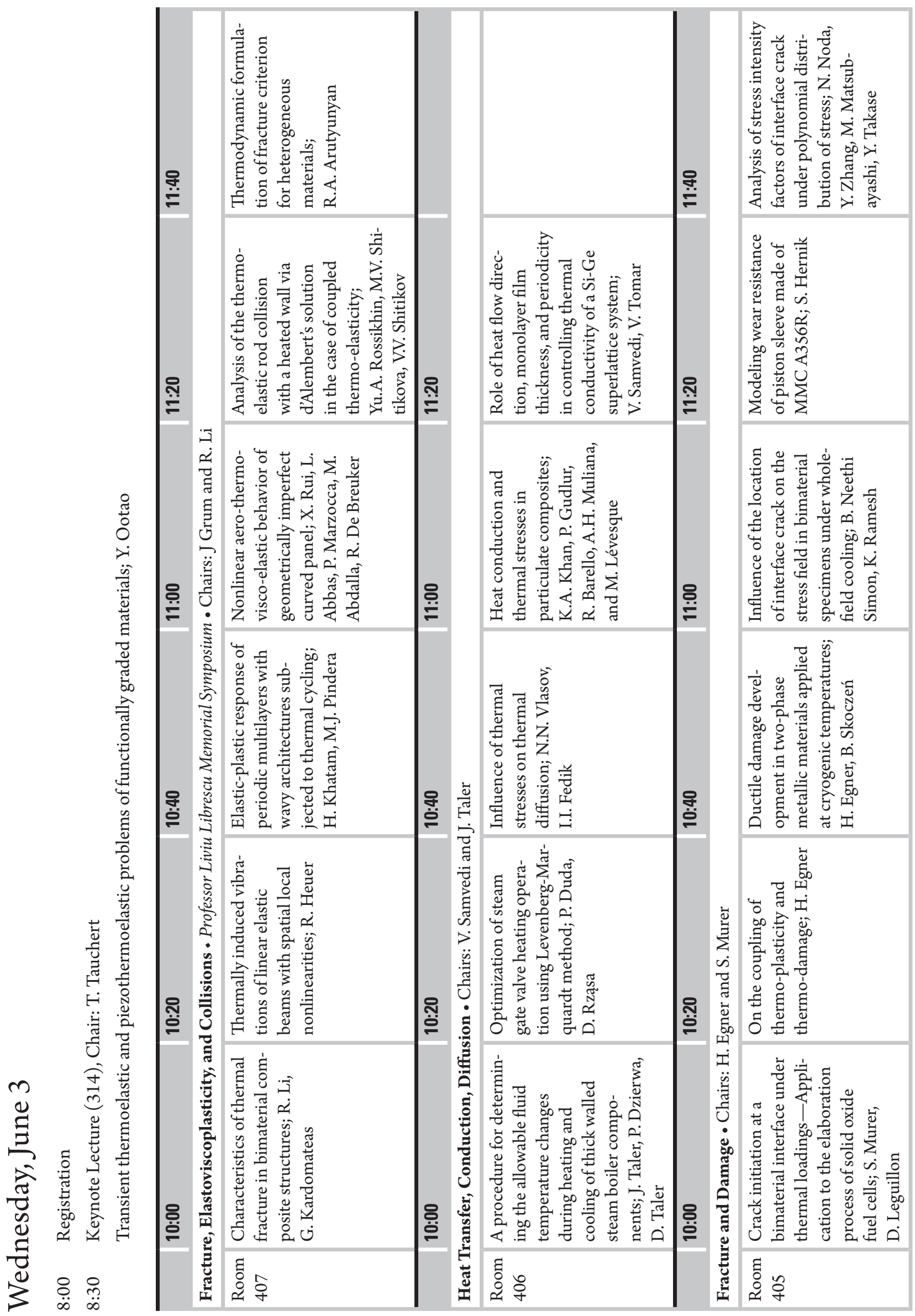




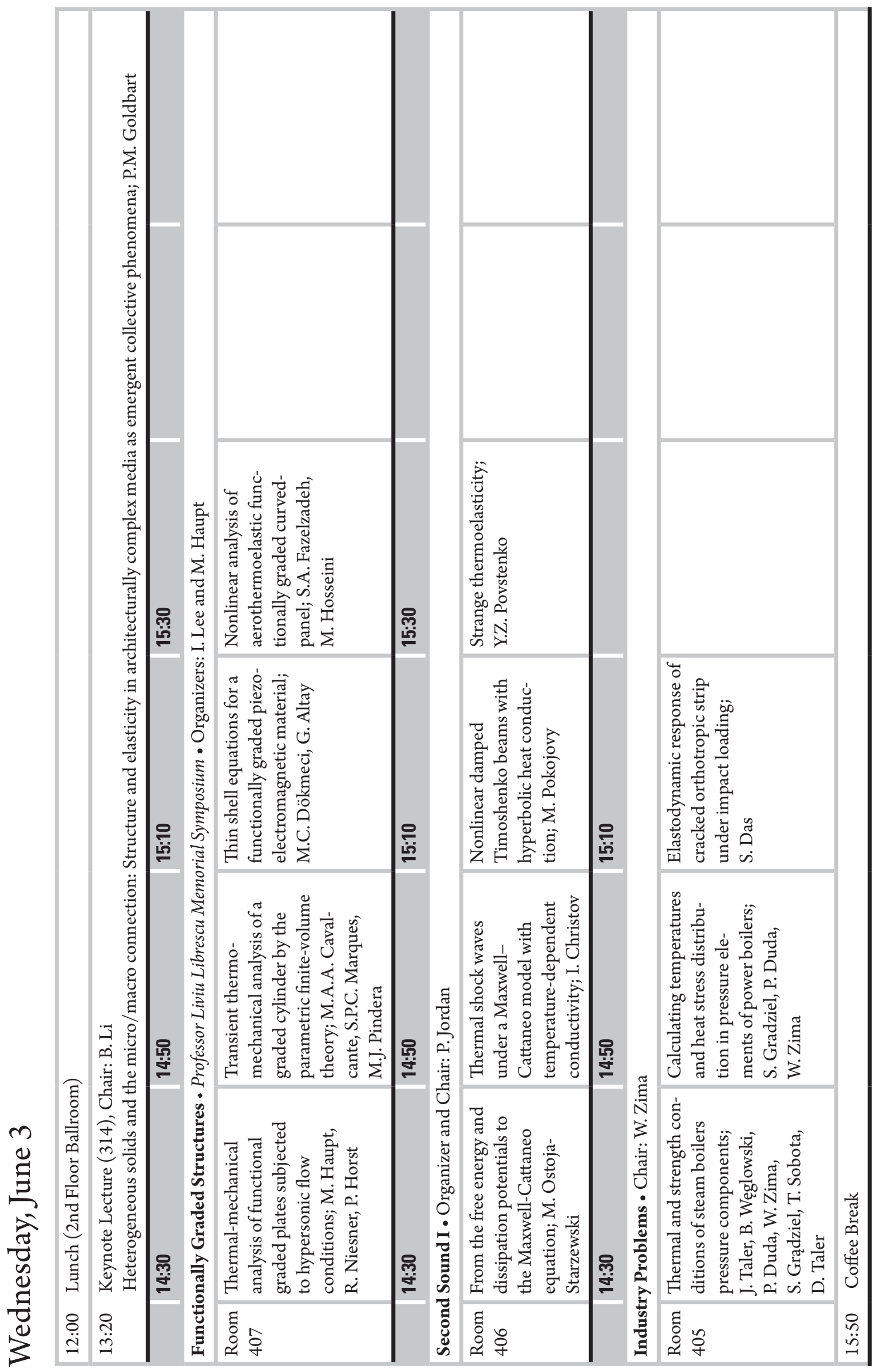




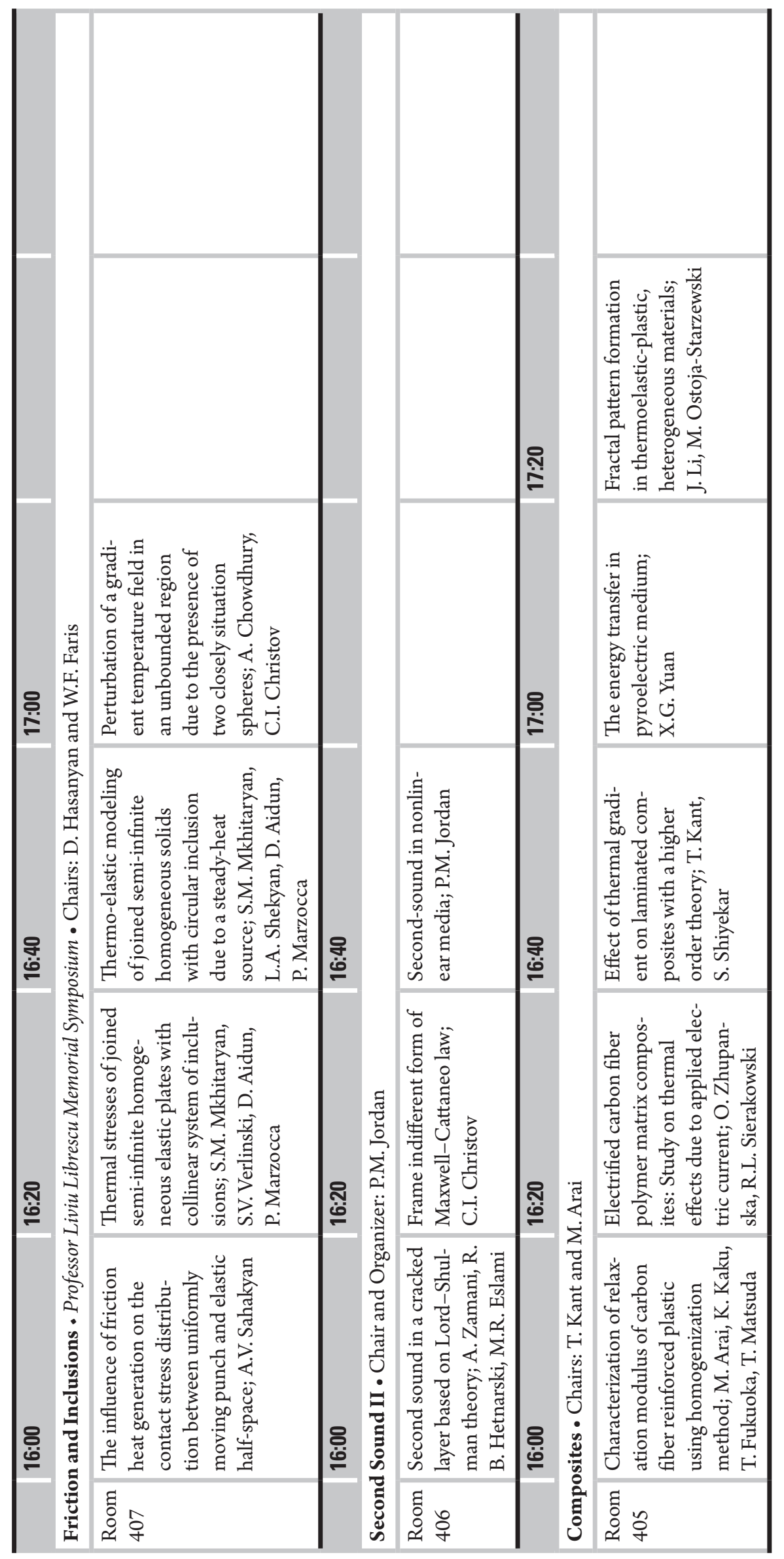




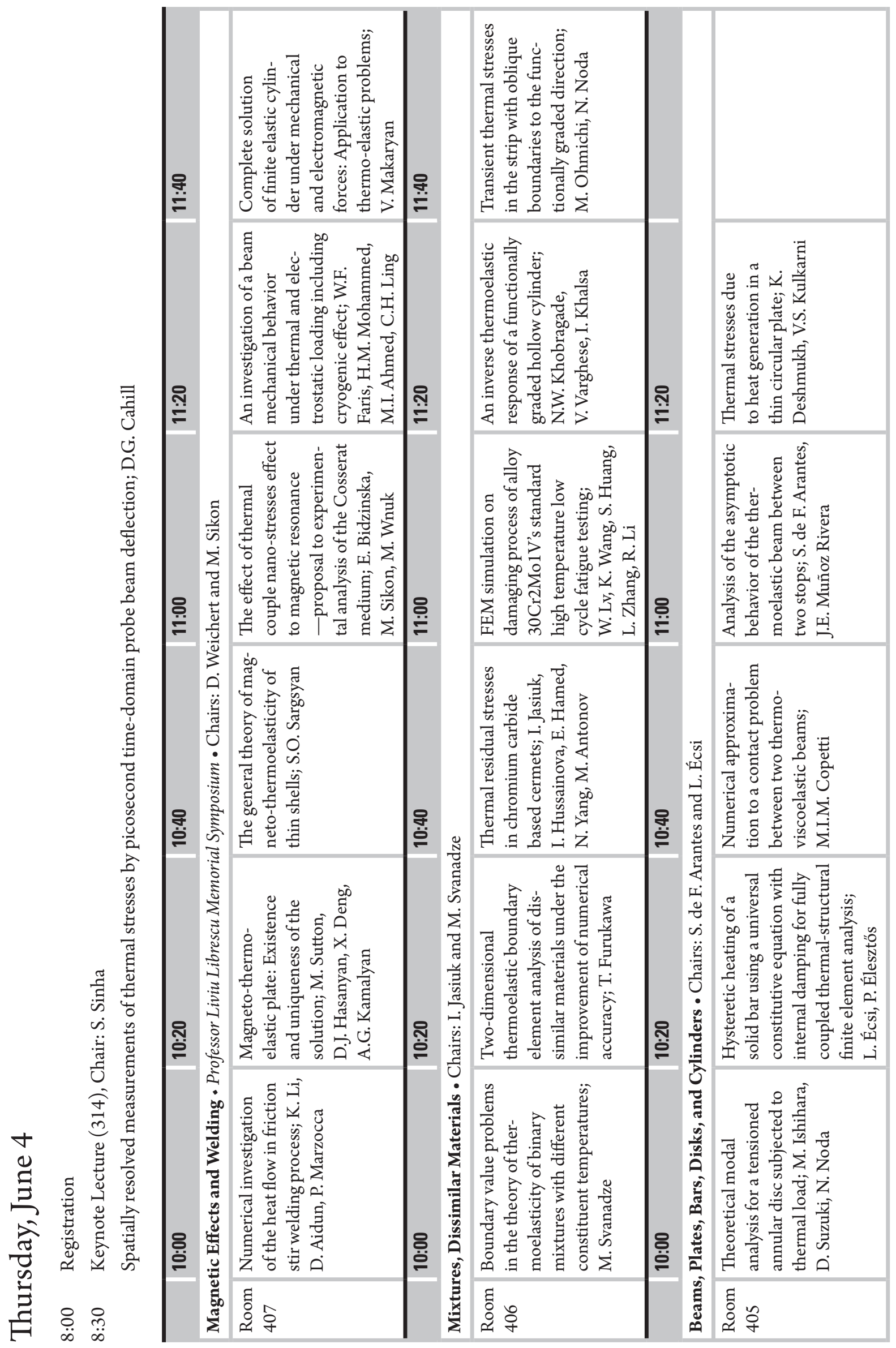




\section{Symposium Sessions}

\section{Thermoelasticity}

\section{Monday, 14:30-16:10 • Room 405}

14:30 Green's functions of axially symmetric static thermoelasticity problems for piecewise-homogeneous space

R. Kushnir, B. Protsiuk, and V. Syniuta

14:50 Anomalous diffusion, heat conduction, and rectification in nanotubes

\section{B. $\mathrm{Li}$}

15:10 Effect of stress ratio and temperature on the small fatigue crack growth behavior of cermets

S. Ishihara, T. Goshima, and M. Shimizu

15:30 On analytical methods for thermoelastic analysis of a rectangle

V. Meleshko and Y. Tokovyy

15:50 Response of thermoelastic medium with one cylindrical bore under moving load

\section{A.B. Kumar}

\section{Inhomogeneity, Nonlinearity, Voids}

\section{Monday, 14:30-16:10 • Room 406}

14:30 Numerical and experimental analysis of thermalinduced residual stresses in epoxy resin based products

T. Nowak, G. Kmita, and R. Sekula

14:50 Thermal stress analysis to predict locations of defects in the solidification process for large-scale cast steel

N.-A. Noda, Y. Tashiro, S. Egawa, and K. Takenouchi

15:10 Reduction of thermal stress for ceramics stalk dipping into molten metal

N.A. Noda, Hendra, W.B. Li, and Y. Takase

15:30 Effect of material inhomogeneity on thermal stresses in a half-plane

Y. Tokovyy and C.C. Ma

\section{Piezo-Effect}

\section{Monday, 14:30-16:10 • Room 407}

14:30 On the problem of reflection of shear wave from a boundary of piezoelectric media of class $6 \mathrm{~mm}$
14:50 Optimum design of a piezo-composite disk for control of thermal stress

\section{A. Elsawaf, F. Ashida, and S. Sakata}

15:10 Least-squares residual solution to an inverse problem of a piezo-thermo-elastic cylinder

T. Tauchert and F. Ashida

15:30 Thermal, electrical, and mechanical response of a piezo-ceramic thin film with damping

N. Sumi and Y. Matsunaga

15:50 On bending waves in an electro-conductive elastic plate

K. Ghazaryan and R. Ghazaryan

\section{Piezo-Thermoelasticity}

\section{Monday, 16:20-17:40 • Room 405}

16:20 Analytical modeling of piezo-SMA composite for thermal energy harvesting

$$
\text { M. Taya and O. Cem Namli }
$$

16:40 Exact solution piezothermoelastic of a transversely isotropic cylindrical shell under axisymmetric loading X.W. Tangpong and O.P. Agrawal

17:00 Electro-thermo-mechanical elasticity of laminated piezoelectric finite length cylinders

T. Kant and P. Desai

17:20 Refection of piezothermoelastic waves from stressfree electroded boundary of a half-space J.N. Sharma and V. Walia

\section{Thermomechanics, Nanoeffects}

\section{Monday, 16:20-18:00 • Room 406}

16:20 Frame-free continuum thermomechanics B.E. Seguin

16:40 Effect of the thermal stresses on electronic properties of GaN/AIN nanowire superlattices

S.R. Patil and R.V.N. Melnik

17:00 On the linear thermoelasticity without energy dissipation

S. Chirita and M. Ciarletta 
17:20 Measurement of the thermal conductivity of ultrathin polymers using time-domain thermoreflectance (TDTR)

M.G. Ghossoub, J.H. Lee, O.T. Baris, D.G. Cahill, and S. Sinha

17:40 Effect of inclusions on the reliability of film-substrate systems

K. Zhou, L.M. Keer, J.Q. Wang, X. Ai, K. Sawamiphakdi, and P. Glaws

\section{Thermal Stresses I}

\section{Monday, 16:20-18:00 • Room 407}

16:20 Thermoelastic interaction between a point heat source and a coated elliptic hole

C.K. Chao, C.K. Chen, and F.M. Chen

16:40 Thermal stress-focusing effect following dynamically transforming strains in a cylindrical zirconia inclusion

\section{T. Hata}

17:00 Thermal stress of strip in preheating furnace of continuous annealing line (CAL)

T.C. Chen, C.H. Ho, J.C. Lin, and L.W. Wu

17:20 Thermal stresses in a finite elastic cylinder V. Meleshko and Y. Tokovyy

17:40 Thermal stresses in a rectangle under sliding builtin support of opposite sides

Y. Tokovyy and C.C. Ma

\section{Fracture and Deformations in} Functional Materials and Structures

\section{Tuesday, 10:00-12:00 • Room 405}

10:00 Transient thermoelectromechanical response of a piezoelectric strip with two parallel cracks of different lengths

\section{S. Ueda and A. Ishii}

10:20 Transient thermoelectromechanical response of a functionally graded piezoelectric material strip with an infinite row of parallel cracks

\section{S. Ueda and Y. Ashida}

10:40 Thermoelectromechanical interaction among multi parallel cracks in a piezoelectric material

\section{S. Ueda and Y. Uemura}

11:00 Thermoelectroelastic response of a functionally graded piezoelectric strip with two parallel pennyshaped or annular cracks

S. Ueda, T. Iogawa, and N. Nishimura
11:20 Thermal stresses in an elastic thick plate containing a spherical cavity with the circular regions of both plate surfaces being heated and cooled

E. Tsuchida, Y. Arai, and S. Kitaoka

11:40 Dynamic thermoelastic problems of thin films with damping

F. Ashida and S. Sakata

\section{Buckling and Stability}

\section{Tuesday, 10:00-12:00 • Room 407}

10:00 Attenuation of thermal creep buckling of columns through designer viscoelastic material properties and tailored servo-controls

H. Hilton, D.H. Lee, and C.G. Merrett

10:20 Thermo-elastic stability of superconductive shell in a homogeneous magnetic field

G.Y. Baghdasaryan, M.A. Mikilyan, and P. Marzocca

10:40 Thermal instabilities in functionally graded MEMS D.J. Hasanyan

11:00 Limit states of structures under thermo-mechanical loads

D. Weichert, A. Hachemi, and S. Mouhtamid

11:20 Flexural-torsional postbuckling behavior of thinwalled frames

N. Rizzi and V. Varano

11:40 Thermal buckling and deformation of aerospace structures and their improvement with shape memory alloys

In Lee, Eun-Ho Kim, and J.-H. Roh

\section{Contact and Instability}

\section{Tuesday, 10:00-12:20 • Room 404}

10:00 Effect of Newtonian cooling on frictionally excited thermoelastic instability in wet friction clutches and brakes

P. Zagrodzki

10:20 Thermoelastic contact of two half-spaces for the case of heat flowing into material of smaller distortivity

R. Martynyak, R. Shvets, and K. Chumak

10:40 Application of Fractional Derivatives in Thermal Analysis of Disk Brakes

O.P. Agrawal

11:00 Frictionally excited thermoelastic instability and suppression of its exponential rising in disc brakes M. Svantner, M. Honner, J. Šroub, and J. Voldřich 
11:20 Frictionally excited thermoelastoplastic instability S. H. Ahn and Y.H. Jang

11:40 Impact loading and yield limit

A. Gruzdkov, N. Morozov, Y. Petrov, and L. Shikhobalov

12:00 Two contact problems with the strip of the frictional heating during braking

A.A. Yevtushenko and M. Kuciej

\section{Magneto- and Micropolar- Thermoelasticity}

\section{Tuesday, 14:30-15:50 • Room 405}

14:30 Thermomagnetoelastic stresses within "latticefluid" state of a vortex field in a superconductor

A. Drzewiecki, B.T. Maruszewski, and R. Starosta

14:50 Analysis of magneto-thermo-elastic response in a functionally graded isotropic unbounded medium based on GN-theory

M. Kanoria and P. Das

15:10 On the linear theory of thermoelasticity with microtemperatures

A. Scalia and M. Svanadze

15:30 Boundary integral method in the linear theory of micropolar thermoelastcity with microtemperatures

M. Svanadze

\section{Wave Propagation}

\section{Tuesday, 14:30-15:50 • Room 406}

14:30 Modeling heat transfer in metal films by a thirdorder derivative-in-time dissipative and dispersive wave equation

\section{J. Ignaczak}

14:50 Thermoelastic wave surfaces in solids

\section{K.L. Verma}

15:10 Thermoelasticity with second sound for viscoelastic mixtures

S. De Cicco and L. Nappa

15:30 Mean wave propagation in the thermoelastic nonsimple material with memory

R. Bhattacharyya

\section{Thermal Stresses II}

\section{Tuesday, 14:30-15:50 • Room 407}

14:30 Thermal stresses (TS), thermomechanics (TM), and thermo-hygro-mechanics (THM)

A. Szekeres, P. Elesztos, and E. Enikov

14:50 Residual stresses after laser aurface remelting of cast iron as a Function of microstructure constituents

\section{R. Šturm and J. Grum}

15:10 Analysis of thermal expansion and stresses of a steam turbine cylinder

T. Yang, S. Huang Runzhe, R. Li, and Y. Tao Ren

15:30 Uncoupled quasi-steady thermoelastic stresses in semi-space heated by surface point-like heat source R.V. Goldstein and V.A. Pinsker

\section{Casting and Solidification}

\section{Tuesday, 16:00-17:20 • Room 405}

16:00 Towards a continuum multiphysics simulation of metal solidification processes

S. Koric, B. G. Thomas, and R. Liu

16:20 Thermal stress analysis scheme considering riser geometric effect on casting process

S.Y. Kwak, J.K. Choi, and C. Cho

16:40 Thermal stress of strip in preheating furnace of continuous annealing line $(\mathrm{CAL})$

T.C. Chen, C.H. Ho, J.C. Lin, and L.W. Wu

17:00 Simulations of residual stresses in resistance spot welding process

R. Dalewski, J. Jachimowicz, and M. Pietrzakowski

\section{Films, Coatings, Layers}

\section{Tuesday, 16:00-17:00 • Room 406}

16:00 Thermal stress in titanium thin films G.A. Porter, C.K. Chao, R.K. Chang

16:20 Transient thermoelastic analysis for multilayered thick strip with piecewise exponential nonhomogeneity

Y. Ootao

16:40 Thermal and chemically induced stress of solid oxide fuel cell laminate under oxidizing/reducing gradient condition

K. Sato, K. Yashiro, T. Hashida, and J. Mizusaki 


\section{Delamination and Fiber Reinforced Materials}

Tuesday, 16:00-17:00 • Room 407

16:00 Influence of delaminations on critical speed of rotating shafts with thermoactive fibers

\section{A. Tylikowski}

16:20 Numerical study on debonding between liner and FW layer of composite pressure vessel

H. Suemasu and T. Wara

16:40 Transient heat conduction of variable stiffness composite laminate

G.F. Abdelal, M.M. Abdalla, and Z. Gurdal

\section{Fracture and Damage}

\section{Wednesday, 10:00-11:40 • Room 405}

10:00 Crack initiation at a bimaterial interface under thermal loadings-Application to the elaboration process of solid oxide fuel cells

S. Murer and D. Leguillon

10:20 On the coupling of thermo-plasticity and thermodamage

H. Egner

10:40 Ductile damage development in two-phase metallic materials applied at cryogenic temperatures

H. Egner and B. Skoczeń

11:00 Influence of the location of interface crack on the stress field in bimaterial specimens under wholefield cooling

B. Neethi Simon and K. Ramesh

11:20 Modeling wear resistance of piston sleeve made of MMC A356R

S. Hernik

\section{Heat Transfer, Conduction, Diffusion}

\section{Wednesday, 10:00-11:40 • Room 406}

10:00 A procedure for determining the allowable fluid temperature changes during heating and cooling of thick walled steam boiler components J. Taler, P. Dzierwa, and D. Taler

10:20 Optimization of steam gate valve heating operation using Levenberg-Marquardt method

P. Duda and D. Rząsa
10:40 Influence of thermal stresses on thermal diffusion N.N. Vlasov and I.I. Fedik

11:00 Heat conduction and thermal stresses in particulate composites

K.A. Khan, P. Gudlur, R. Barello, A.H. Muliana, and M. Lévesque

11:20 Role of heat flow direction, monolayer film thickness, and periodicity in controlling thermal conductivity of a Si-Ge superlattice system

V. Samvedi and V. Tomar

\section{Fracture, Elastoviscoplasticity, and Collisions}

\section{Wednesday, 10:00-12:00 • Room 407}

10:00 Thermally induced vibrations of linear elastic beams with spatial local nonlinearities

R. Heuer

10:20 Elastic-plastic response of periodic multilayers with wavy architectures subjected to thermal cycling

H. Khatam and M.J. Pindera

10:40 Nonlinear aero-thermo-visco-elastic behavior of geometrically imperfect curved panel

X. Rui, L. Abbas, P. Marzocca, M. Abdalla, and R. De Breuker

11:00 Analysis of the thermo-elastic rod collision with a heated wall via d'Alembert's solution in the case of coupled thermo-elasticity

Yu.A. Rossikhin, M.V. Shitikova, and V.V. Shitikov

11:20 Characteristics of thermal fracture in bimaterial composite structures

R. Li and G. Kardomateas

11:40 Thermodynamic formulation of fracture criterion for heterogeneous materials

R.A. Arutyunyan

\section{Second Sound I}

\section{Wednesday, 14:30-15:50 • Room 404}

14:30 From the free energy and dissipation potentials to the Maxwell-Cattaneo equation

M. Ostoja-Starzewski

14:50 Thermal shock waves under a Maxwell-Cattaneo model with temperature-dependent conductivity

I. Christov 
15:10 Nonlinear damped Timoshenko beams with hyperbolic heat conduction

M. Pokojovy

15:30 Strange thermoelasticity

Y.Z. Povstenko

\section{Industry Problems}

\section{Wednesday, 14:30-15:30 • Room 405}

14:30 Thermal and strength conditions of steam boilers pressure components

J. Taler, B. Węglowski, P. Duda, W. Zima, S. Grądziel, T. Sobota, and D. Taler

14:50 Calculating temperatures and heat stress distribution in pressure components

S. Gradziel, P. Duda, and W. Zima

15:10 Elastodynamic response of cracked orthotropic strip under impact loading

S. Das

\section{Functionally Graded Structures}

\section{Wednesday, 14:30-15:50 • Room 407}

14:30 Thermal-mechanical analysis of functional graded plates subjected to hypersonic flow conditions

M. Haupt, R. Niesner, and P. Horst

14:50 Transient thermo-mechanical analysis of a graded cylinder by the parametric finite-volume theory

M.A.A. Cavalcante, S.P.C. Marques, and M.J. Pindera

15:10 Thin shell equations for a functionally graded piezoelectromagnetic material

M.C. Dökmeci and G. Altay

15:30 Nonlinear analysis of aerothermoelastic functionally graded curved-panel

S.A. Fazelzadeh and M. Hosseini

\section{Second Sound II}

\section{Wednesday, 16:00-17:00 • Room 404}

16:00 Second sound in a cracked layer based on LordShulman theory

A. Zamani, R.B. Hetnarski, and M.R. Eslami

16:20 Frame indifferent form of Maxwell-Cattaneo law C.I. Christov

16:40 Second-sound in nonlinear media P.M. Jordan

\section{Composites}

\section{Wednesday, 16:00-17:40 • Room 405}

16:00 Characterization of relaxation modulus of carbon fiber reinforced plastic using homogenization method

M. Arai, K. Kaku, T. Fukuoka, and T. Matsuda

16:20 Electrified carbon fiber polymer matrix composites: Study on thermal effects due to applied electric current

O. Zhupanska and R.L. Sierakowski

16:40 Effect of thermal gradient on laminated composites with a higher order theory

T. Kant and S. Shiyekar

17:00 The energy transfer in pyroelectric medium X.G. Yuan

17:20 Fractal pattern formation in thermoelastic-plastic, heterogeneous materials

J. Li and M. Ostoja-Starzewski

\section{Friction and Inclusions}

\section{Wednesday, 16:00-17:20 • Room 407}

16:00 The influence of friction heat generation on the contact stress distribution between uniformly moving punch and elastic half-space

\section{A.V. Sahakyan}

16:20 Thermal stresses of joined semi-infinite homogeneous elastic plates with collinear system of inclusions

S.M. Mkhitaryan, S.V. Verlinski, D. Aidun, and P. Marzocca

16:40 Thermo-elastic modeling of joined semi-infinite homogeneous solids with circular inclusion due to a steady-heat source

S.M. Mkhitaryan, L.A. Shekyan, D. Aidun, and P. Marzocca

17:00 Perturbation of a gradient temperature field in an unbounded region due to the presence of two closely situation spheres

A. Chowdhury and C.I. Christov 


\section{Beams, Plates, Bars, Disks, and \\ Cylinders}

\section{Thursday, 10:00-11:40 • Room 405}

10:00 Theoretical model analysis for a tensioned annular disc subjected to thermal load

M. Ishihara, D. Suzuki, and N. Noda

10:20 Hysteretic heating of a solid bar using a universal constitutive equation with internal damping for fully coupled thermal-structural finite element analysis

L. Écsi and P. Élesztös

10:40 Numerical approximation to a contact problem between two thermoviscoelastic beams

M.I.M. Copetti

11:00 Analysis of the asymptotic behavior of the thermoelastic beam between two stops

S. de F. Arantes and J.E. Muñoz Rivera

11:20 Thermal stresses due to heat generation in a thin circular plate

K. Deshmukh and V.S. Kulkarni

\section{Mixtures, Dissimilar Materials}

\section{Thursday, 10:00-12:00 • Room 406}

10:00 Boundary value problems in the theory of thermoelasticity of binary mixtures with different constituent temperatures

\section{Svanadze}

10:20 Two-dimensional thermoelastic boundary element analysis of dissimilar materials under the improvement of numerical accuracy

\section{T. Furukawa}

10:40 Thermal residual stresses in chromium carbide based cermets

I. Jasiuk, I. Hussainova, E. Hamed, N. Yang, and M. Antonov
11:00 FEM simulation on damaging process of alloy 30Cr2Mo1V's standard high temperature low cycle fatigue testing

W. Lv, K. Wang, S. Huang, R. Li, and L. Zhang

11:20 An inverse thermoelastic response of a functionally graded hollow cylinder

N.W. Khobragade, V. Varghese, and L. Khalsa

11:40 Transient thermal stresses in the strip with oblique boundaries to the functionally graded direction

M. Ohmichi and N. Noda

\section{Magnetic Effects and Welding}

\section{Thursday, 10:00-12:00 • Room 407}

10:00 Numerical investigation of the heat flow in friction stir welding process

K. Li, D. Aidun, and P. Marzocca

10:20 Magneto-thermo-elastic plate: Existence and uniqueness of the solution

M. Sutton, D.J. Hasanyan, X. Deng, and A.G.

Kamalyan

10:40 The general theory of magneto-thermoelasticity of thin shells

S.O. Sargsyan

11:00 The effect of thermal couple nano-stresses effect to magnetic resonance-proposal to experimental analysis of the Cosserat medium

E. Bidzinska, M. Sikon, and M. Wnuk

11:20 An investigation of a beam mechanical behavior under thermal and electrostatic loading including cryogenic effect

W.F. Faris, H.M. Mohammed, M.I. Ahmed, and C.H. Ling

11:40 Complete solution of finite elastic cylinder under mechanical and electromagnetic forces: Application to thermoelastic problems

V. Makaryan 


\section{Author Index to Proceedings, Volumes I and II}

Abbas, L. K. ................................ 99

Abdalla, M. ................................... 99

Abdalla, M. M. .................................. 73

Abdelalm, G. F.......................... 73

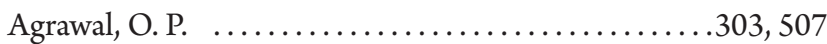

Ahmed, M. I. ................................. 161

Ahn, S.-H. ................................ 309

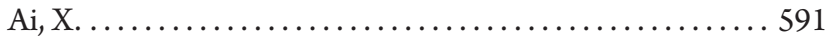

Aidun, D. .......................113, 121, 145

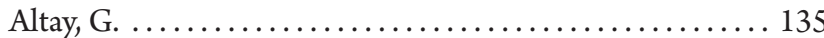

Antonov, M. ............................. 483

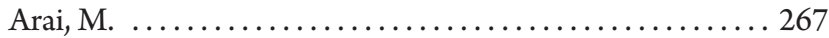

Arai, Y. ...................................... 379

Arantes, S. de F.. ............................... 241

Arutyunyan, R. A. .......................... 87

Ashida, F. ................... 171, 175, 367, 383

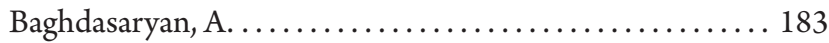

Baghdasaryan, G. Y. .......................... 51

Barello, R. ...................................... 407

Baris, O. T. ............................. 587

Belubekyan, M. .......................... 183

Berezovski, A.................................

Bhattacharyya, R. ............................. 609

Bidzinska, E. ............................ 157

Brock, L. M. ................................

Cahill, D. G. .........................41, 587

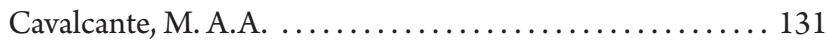

Cem Namli, O. ........................... 503

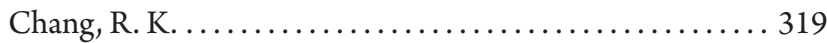

Chao, C. K. .........................21, 193, 319

Chen, C. K. ................................. 193

Chen, F. M. ........................... 193

Chen, T.-C. ........................201, 257

Chiriță, S.................................. 583

Cho, C..................................... 253

Choi, J. K. .............................. 253

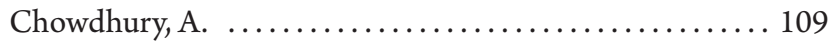

Christov, C. I. ..........................109, 543

Christov, I. ................................. 525

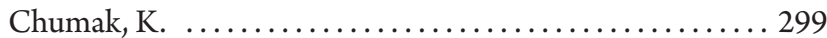

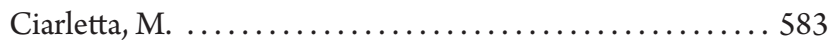

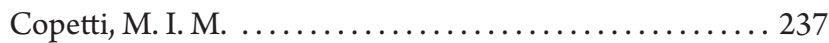

Dalewski, R. ................................... 261

Das, P. . . .

429,461

DeBreuker, R............................. 99

De Cicco, S. ................................. 605

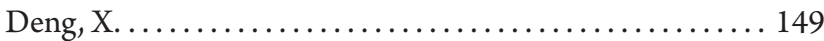

Desai, P. .................................... 511

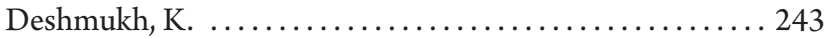

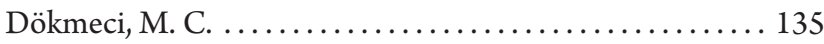

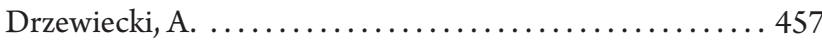

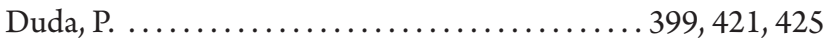

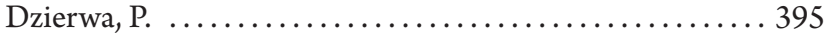

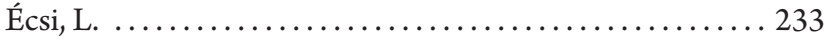

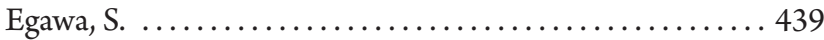

Egner, H. .................................... 345

Elesztos, P. ..........................213, 233

Elsawaf, A. ............................. 171

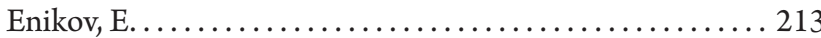

Eslami, M. R. ................................. 539

Faris, W F. .................................. 161

Fazelzadeh, S. A. ............................ 139

Fedik, I. I. ............................... 403

Florea, O. ................................... 165

Fukuoka, T. ................................... 267

Furukawa, T. ............................ 479

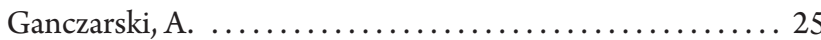

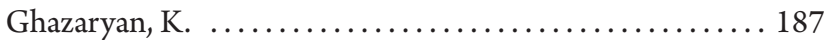

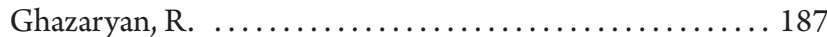

Ghossoub, M. G. .......................... 587

Glaws, P.............................. 591

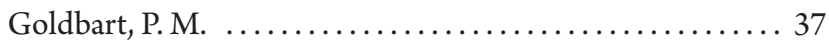

Goldstein, R. V. ............................ 213

Goshima, T. ............................. 561

Grądziel, S. ........................421, 425

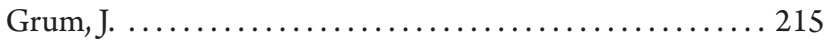

Gruzdkov, A. ...................................... 313

Gudlur, P................................. 407

Gurdal, Z. ............................ 73

Hachemi, A. ............................ 59

Hamed, E. ................................. 483

Hasanyan, D. J. ..........................55, 149

Hashida, T. ............................... 327

Hata, T. .............................. 197

Hatami-Marbini, H. . . . . . . . . . . . . . . . . . . . . . . . . . . 389

Haupt, M. .............................. 127

Hendra ................................. 443

Hernik, S. ............................ 353

Hetnarski, R. B. ................................ 539

Heuer, R. ................................ 91

Hilton, H. H. ......................... 47

Ho, C.-H. ........................201, 257 


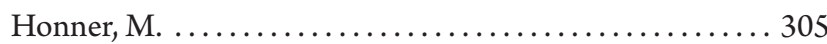

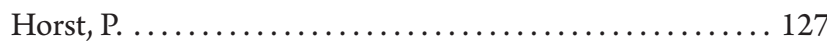

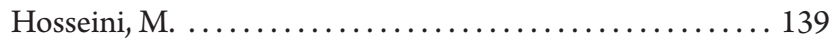

Huang, S. .........................219, 487

Hussainova, I. .......................... 483

Ignaczak, J. .......................... 597

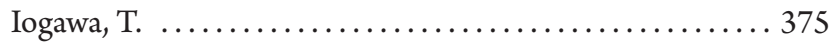

Ishihara, M. . . . . . . . . . . . . . . . . . . . . . . . . . . . . . 229

Ishihara, S. ............................ 561

Ishii, A. ...................................... 363

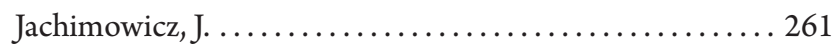

Jang, Y. H. ........................................ 309

Jasiuk, I. .......................... 483

Jordan, P. M. ............................... 547

Kaku, K. .................................. 267

Kamalyan, A. G............................ 149

Kanoria, M................................ 461

Kant, T. ...............................275, 511

Kardomateas, G. ....................... 83

Keer, L. M. .............................. 591

Khalsa, L. ................................ 491

Khan, K. A. .................................. 407

Khatam, H. ................................ 95

Khobragade, N. W. ........................ 491

Kim, E.-H. ........................... 65

Kitaoka, S. .................................... 379

Kmita, G. .......................... 435

Koric, S. ............................. 249

Kuciej, M. .............................. 289

Kulkarni, V. S. ................................. 243

Kumar, A. B. ............................. 569

Kushnir, R. .......................... 553

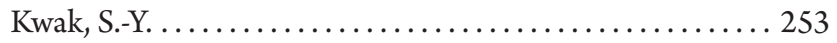

Lee, D. H. .................................. 47

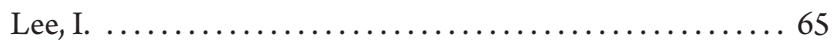

Lee, J. H. .......................... 587

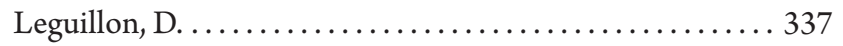

Lévesque, M. ................................. 407

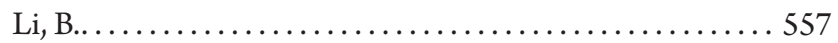

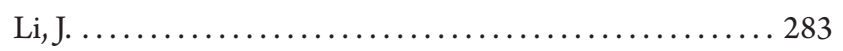

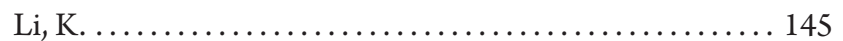

Li, R................................. 83

Li, W. B. ................................. 443

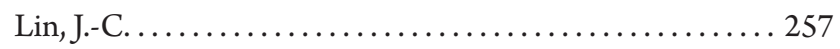

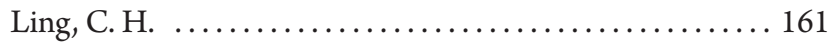

Liu, R.................................... 249

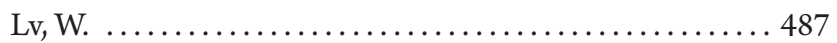

Ma, C.-C............................207, 447
Malanchuk, N. ............................411

Marin, M. ........................... 451

Marques, S. P. C. ........................... 131

Martynyak, R. ............................. 299

Martynyak, R. ............................. 411

Maruszewski, B. T. ............................ 457

Marzocca, P. .................. 51, 99, 113, 121, 145

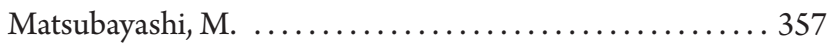

Matsuda, T. ................................... 267

Matsunaga, Y. .............................. 179

Maugin, G. A. ..............................

Meleshko, V. ............................205, 565

Melnik, R. V. N. ................................ 579

Merrett, C. G. .............................. 47

Mikilyan, M. A. ............................ 51

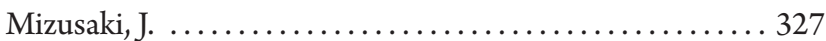

Mkhitaryan, S. M. .......................113, 121

Mohammed, H. M. ............................ 161

Monastyrskyy, B. ......................... 411

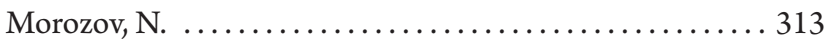

Mouhtamid, S. .............................. 59

Muliana, A. H. ................................ 407

Muñoz Rivera, J. E. ............................... 241

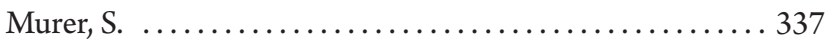

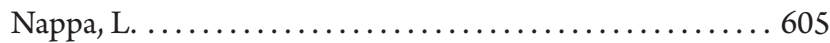

Neethi Simon, B. .......................... 349

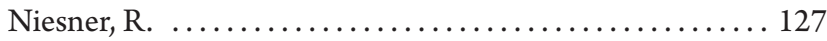

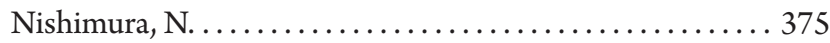

Noda, N. .............................229, 497

Noda, N.-A....................... 357, 439, 443

Noll, W. ............................... 13

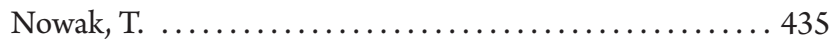

Ohmichi, M. ........................... 497

Ootao, Y. .................................... 323

Ostoja-Starzewski, M. ...................283, 521

Patil, S. R. ............................. 579

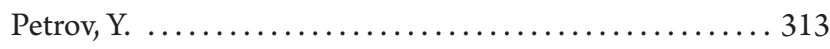

Pietrzakowski, M. ............................. 261

Pindera, M.-J. ..........................95, 131

Pinsker, V. A............................. 223

Pokojovy, M. ............................... 529

Porter, G. A. .................................. 319

Povstenko, Y. Z. ................................. 533

Protsiuk, B. .................................. 553

Ramesh, K. .................................. 349

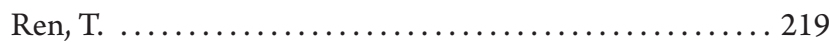

Rizzi, N. L.................................. 63

Roh, J.-H.................................. 65 


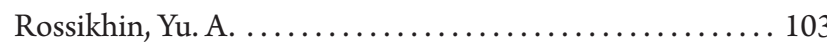

Rui, X. ................................ 99

Rzasa, D. ................................. 399

Sahakyan, A. V. .......................... 117

Sakata, S. ..........................171, 383

Samvedi, V. ................................. 415

Sargsyan, S. O. ........................... 153

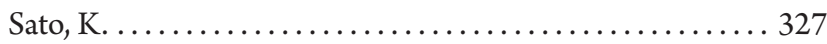

Sawamiphakdi, K. .......................... 591

Scalia, A. ................................... 465

Seguin, B. E. ............................ 575

Sekula, R...................................... 435

Sharma, J. N. .................................. 515

Shekyan, L. A. .................................. 113

Shikhobalov, L. ............................... 313

Shimizu, M............................... 561

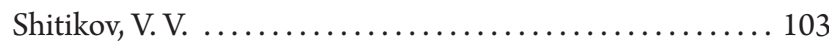

Shitikova, M. V. ............................. 103

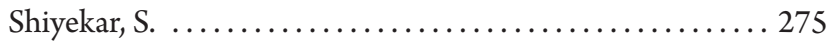

Shodja, H. M. .............................. 389

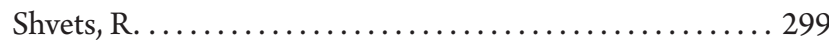

Sierakowski, R. L. ........................... 271

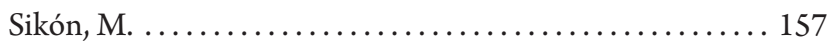

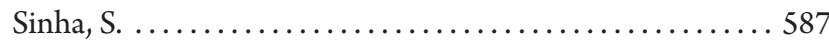

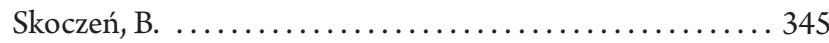

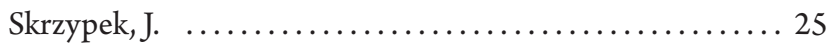

Sobota, T. .............................. 421

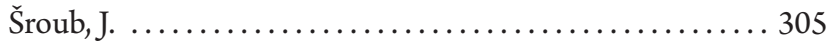

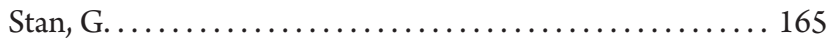

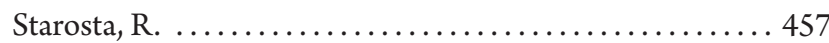

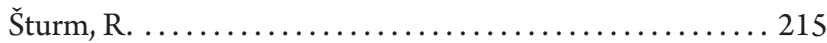

Suemasu, H. ................................ 69

Sumi, N. ............................. 179

Sutton, M. ................................. 149

Suzuki, D. .................................... 220

Svanadze, M........................465, 475

Svanadze, M. M. ............................. 479

Syniuta, V. .................................. 553

Szekeres, A. ................................ 213

Takase, Y. .................................. 443

Takenouchi, K................................ 439

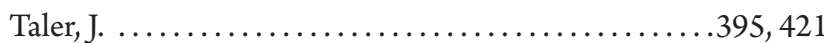

Taler, D. ........................................ 421

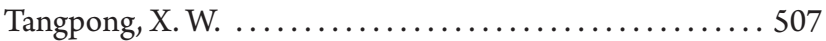

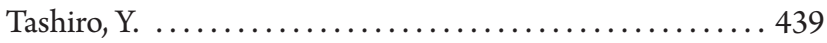

Tauchert, T. ............................ 175

Taya, M. .................................. 503

Thomas, B. G. ............................. 249

Tokovyy, Yu. .................. 205, 207, 447, 565

Tomar, V. ............................... 415

Tsuchida, E. ..................................... 379

Tylikowski, A. ........................... 77

Ueda, S. .................... 363, 367, 371, 375

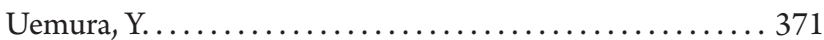

Varano, V................................. 63

Varghese, $V . \ldots \ldots \ldots \ldots \ldots \ldots \ldots \ldots \ldots \ldots \ldots . \ldots . \ldots . \ldots 1$

Verlinski, S. V. .......................... 121

Verma, K. L. ................................. 601

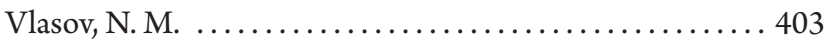

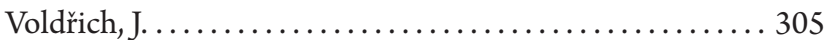

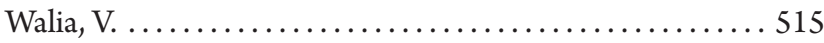

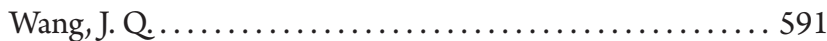

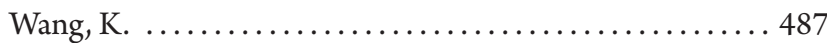

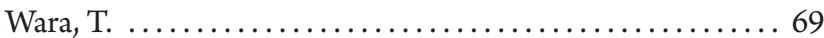

Węglowski, B. ............................ 421

Weichert, D. ................................ 59

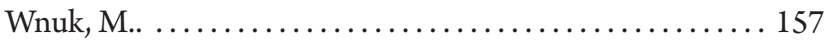

Wu, L.-W...........................201, 257

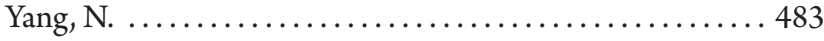

Yang, R. ................................... 219

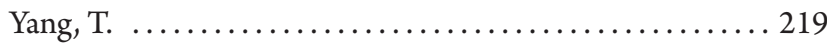

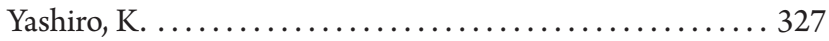

Yevtushenko, A. A. .......................... 289

Yuan, X.-G. ............................... 279

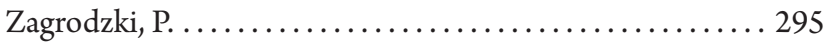

Zamani, A................................... 539

Zhang, L. ............................. 487

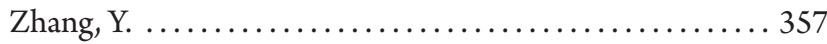

Zhao, J.-C. ............................ 41

Zheng, X................................. 41

Zhou, K. ............................... 591

Zhupanska, O. ........................... 271

Zima, W. ............................421, 425 


\section{Notes}




\section{Illini Union Floor Plan}

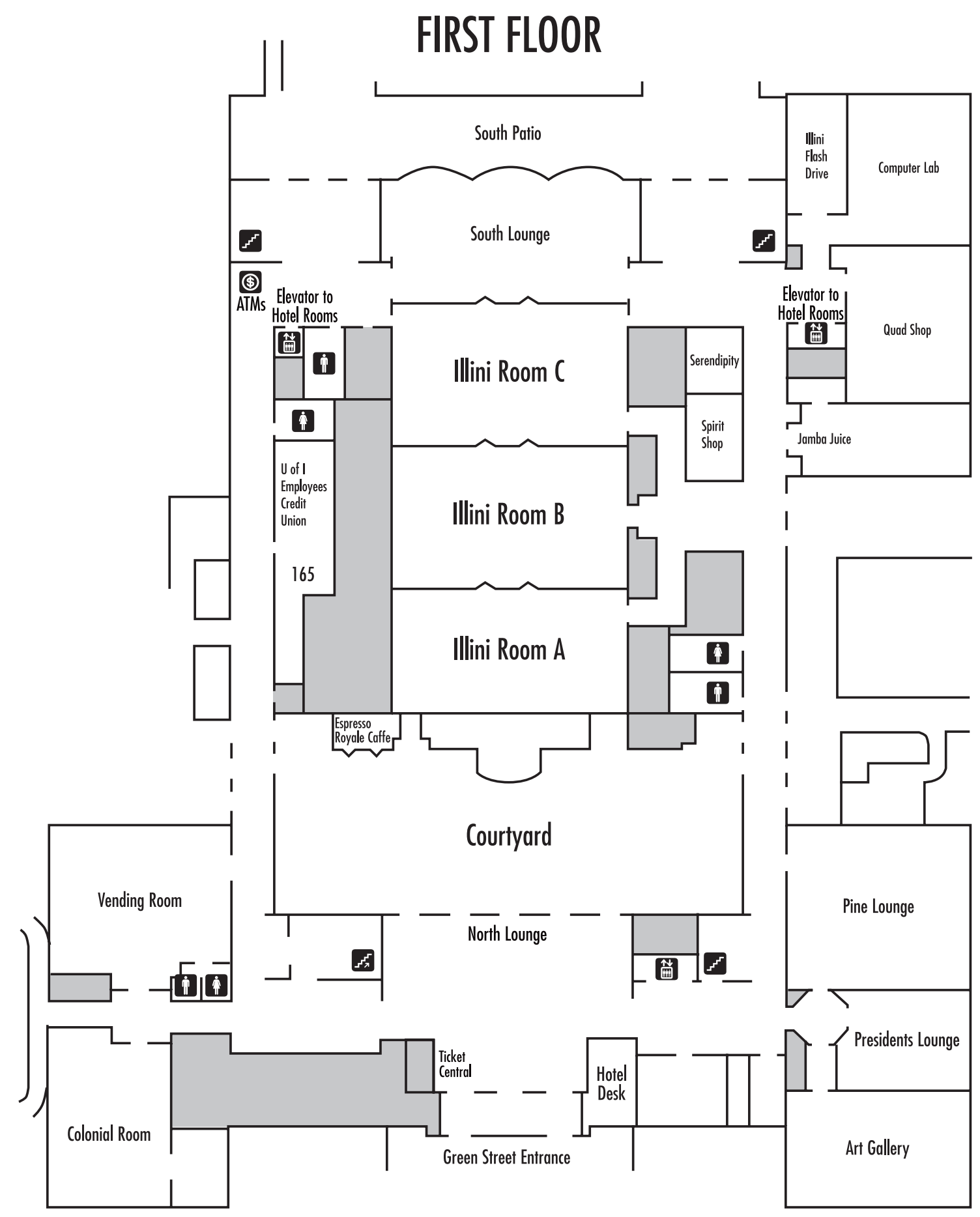



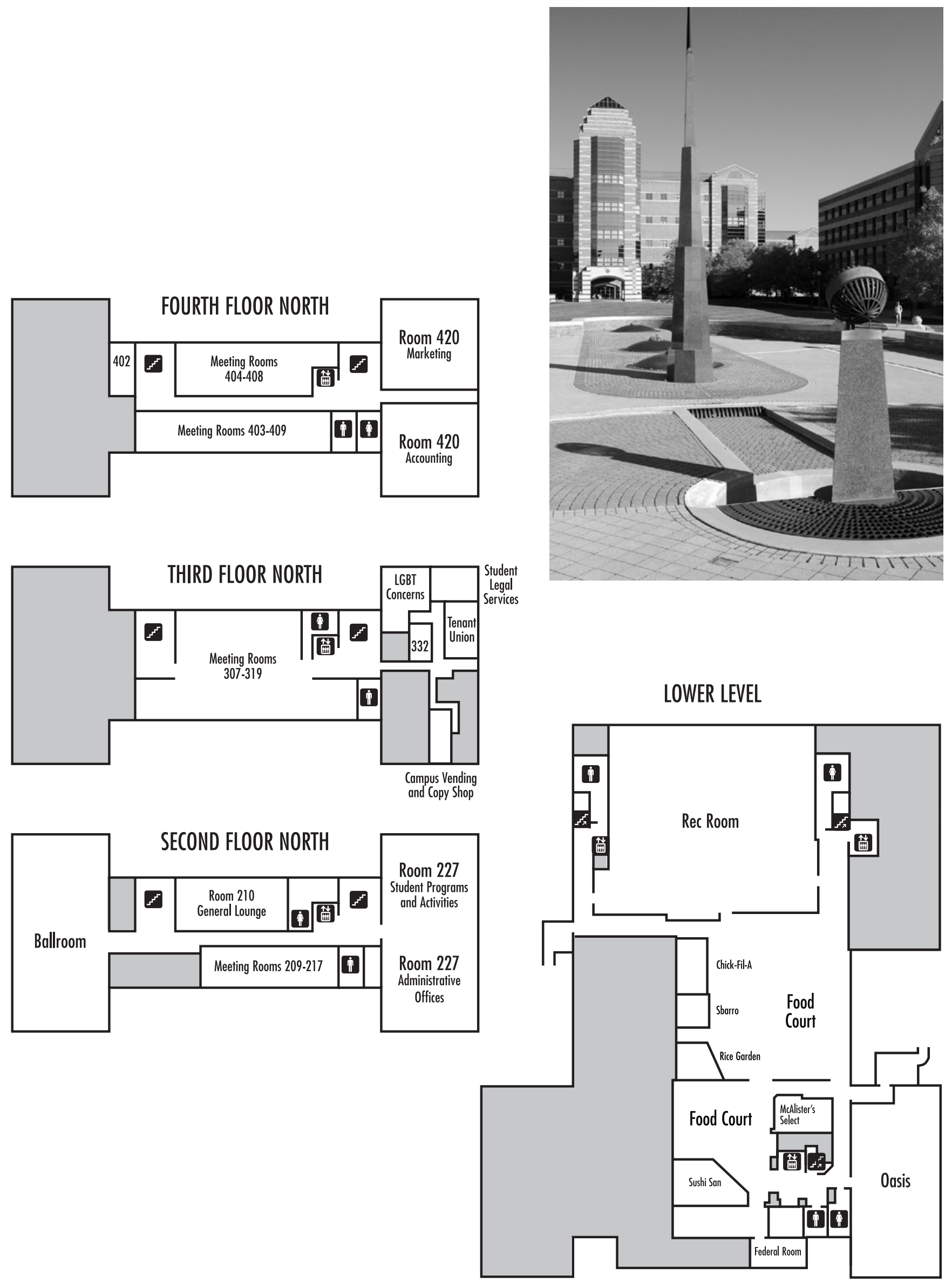


\title{
FREE Online Access to Journal of Thermal Stresses!
}

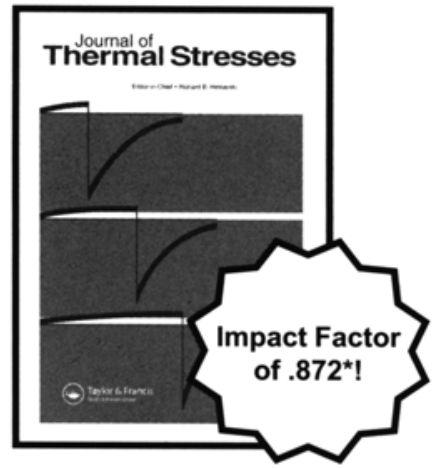

\author{
8th International Congress on \\ the full online content of \\ Journal of Thermal Stresses \\ FREE for 30 days!
} Thermal Stresses attendees can view

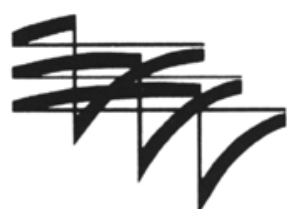

The first international journal devoted exclusively to the subject, Journal of Thermal Stresses publishes refereed articles on the theoretical and industrial applications of thermal stresses. Intended as a forum for those engaged in analytic as well as experimental research, this journal includes papers on mathematical and practical applications. Emphasis is placed on new developments in thermoelasticity, thermoplasticity, and theory and applications of thermal stresses. Papers on experimental methods and on numerical methods, including finite element methods, are also published.

\section{Highly Cited Articles}

- Axially Critical Load of Multiwall Carbon Nanotubes Under Thermal Environment, $X$. Wang, H.K. Yang, and X.C. Yin

- The Crack Problem in Piezoelectric Strip Under Thermoelectric Loading, S. Ueda

- Thin-Walled Beams Made of Functionally Graded Materials and Operating in a High Temperature Environment: Vibration and Stability, L. Librescu, S.Y. Oh, and O. Song

- Mesoscale Analysis of Shear Bands in High Strain Rate Deformations of Tungsten/Nickel-Iron Composites, R.C. Batra and B.M. Love

- Fractional Heat Conduction Equation and Associated Thermal Stress, Y.Z. Povstenko

- Thermoelastic Analysis of Thick-Walled Finite-Length Cylinders of Functionally Graded Materials, M. Ruhi, A. Angoshtari, and R. Naghdabadi

To access this special offer, email onlineresource@taylorandfrancis.com and mention Journal of Thermal Stresses and 8th International Congress on Thermal Stresses in the email.

For further information and to submit a manuscript, visit the journal's website: www.tandf.co.uk/journals/UTHS

Editor-in-Chief: Richard B. Hetnarski Vol. 32, (2009) • Monthly

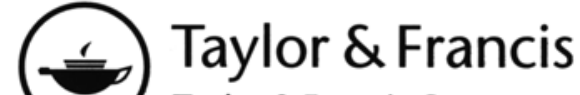

Taylor \& Francis Group 